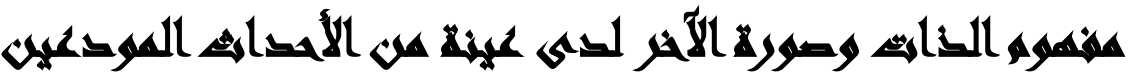

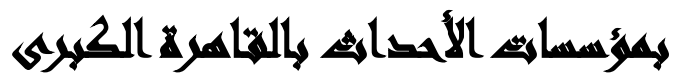

[V]

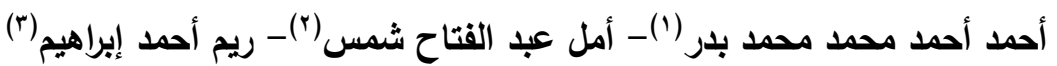

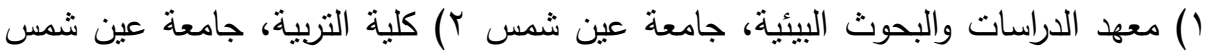
r) كلية التربية الرياضية، جامعة حلوان التوان

\section{المسريطلى}

يحاول الإنسان بشكلٍ مستمر التعرّف على أعماق ذاته لتحديد توجهاتها وملامح

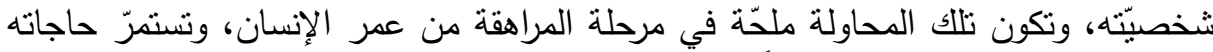

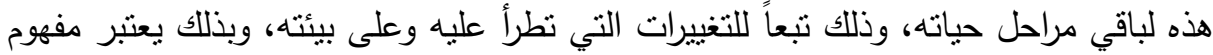

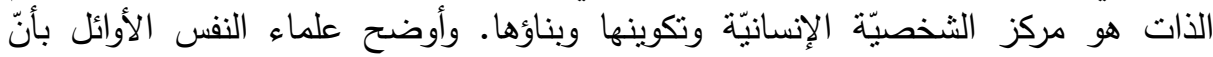

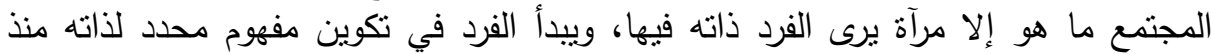

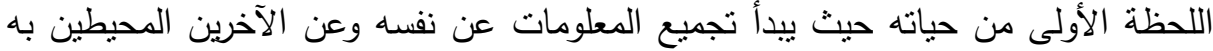

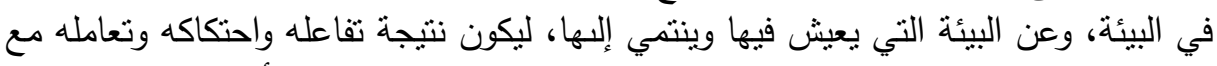

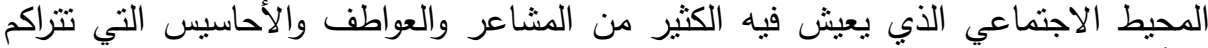

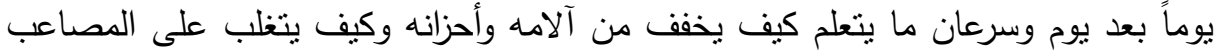

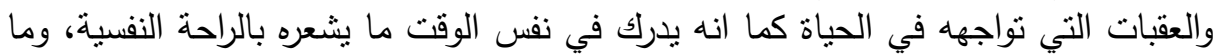

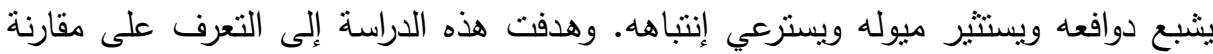

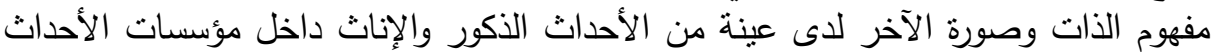

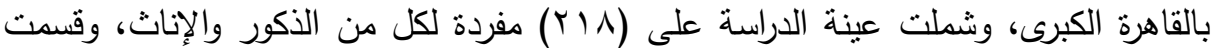

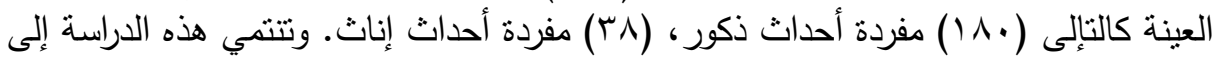

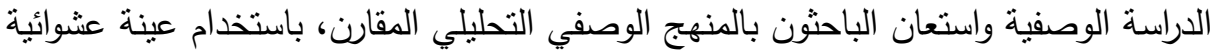

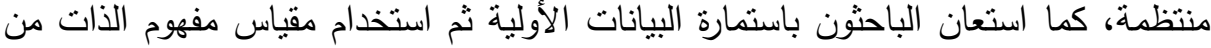

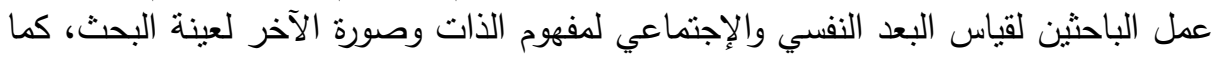

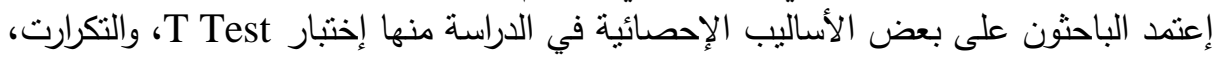

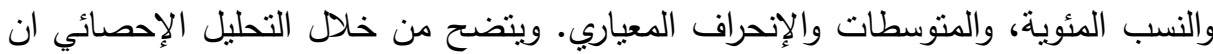

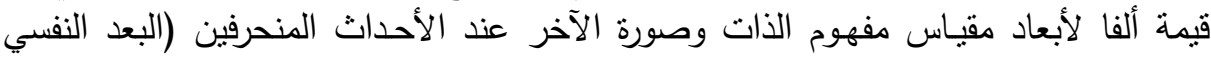

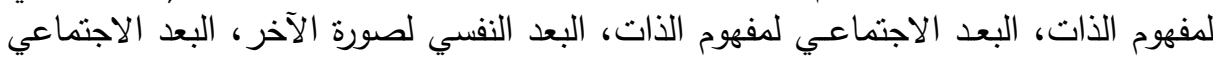

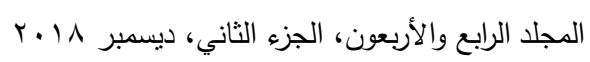




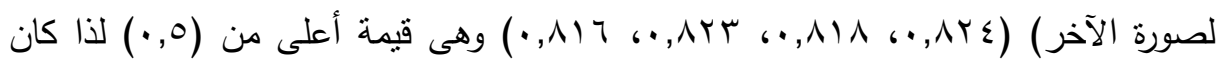

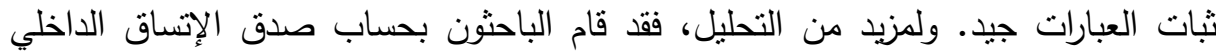

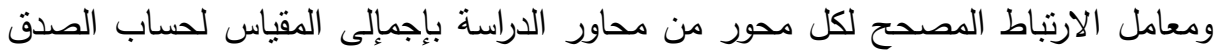

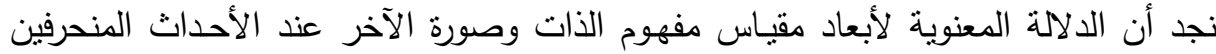

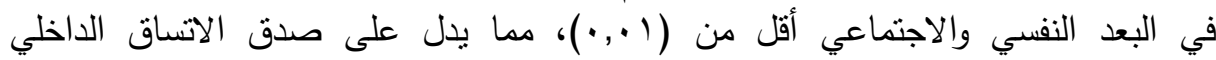

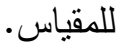

وقد توصلت الدراسة للنتائج الثالية: أنه لاتوجد فروق ذات دلالة إحصائية بين الذكور

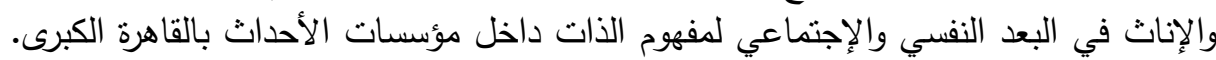

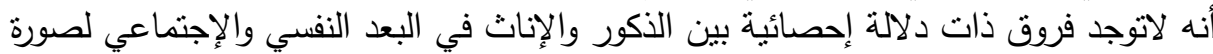

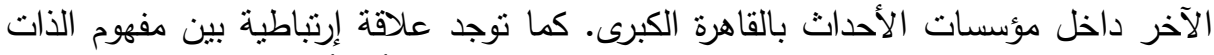

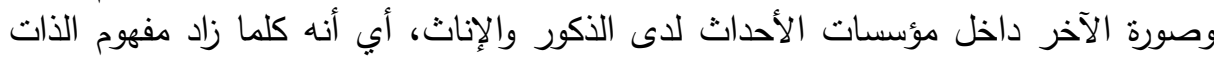

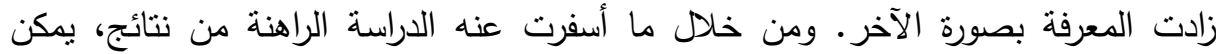
للباحثين أن يقدموا بعض التوصيات التالية: ضرورة العمل على بث الثيل القيم الإيجابية للأحداث

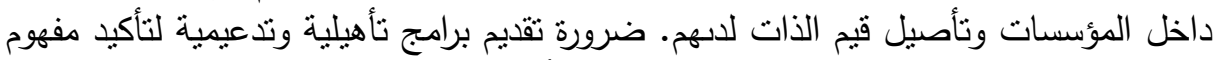

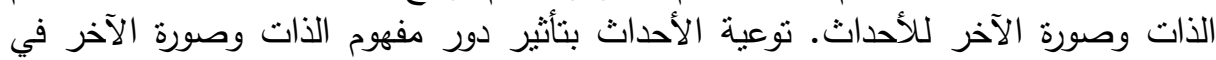

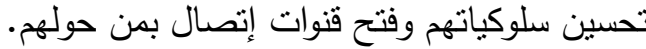

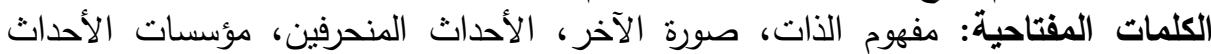

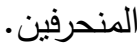

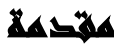

تعد ظاهرة انحراف الأحداث من أبرز الظواهر الاجتماعية المخلة بالنظام الاجتماعي في

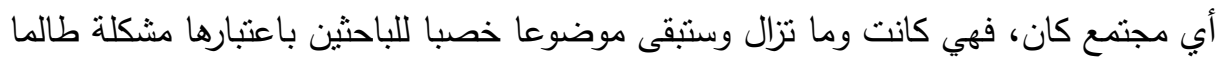

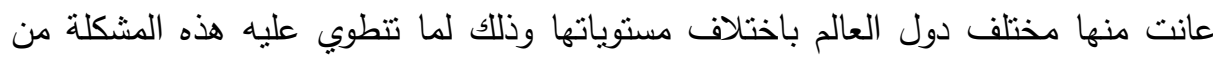

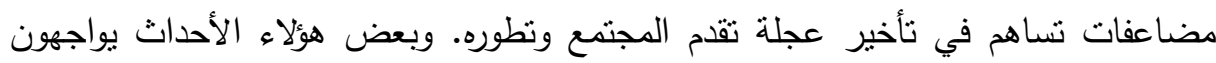

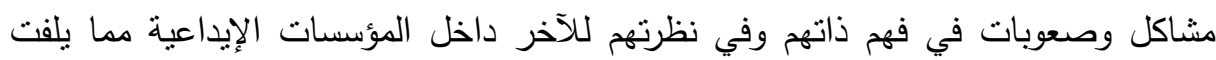

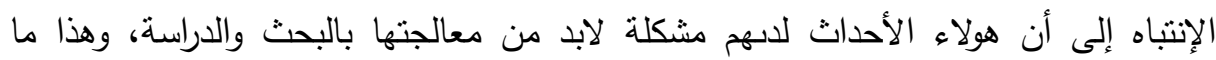

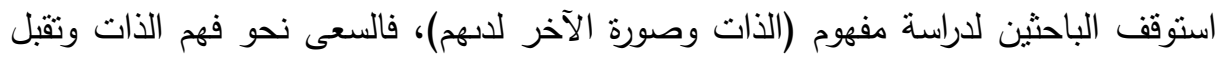

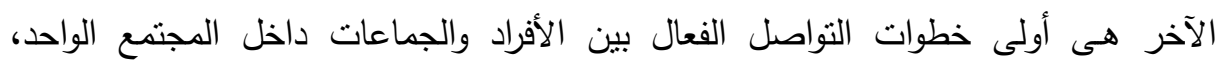
ووسيلة أساسية لفهم الفرد عن ذاته وايضا فهمه وتثقله للاخرين. والتساؤل هنا عن مدى فهم 
الحدث لذاته ومدى تقبله للآخر • ومن خلال الوصف التام والتحليل العميق للاراسة نستطيع من خلاله الإجابة عن هذا التساؤل الفعال. وأن (مفهوم الذات) هو مفهوم ينمو من خلال الخبرات الجزئية والمواقف التى يمر بها

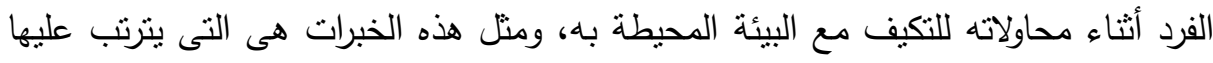
نمو التظيمات السلوكية المختلفة بناء على عملية التعلم، وهذا المفهوم (الذات) يحدد أداء الثخص الفعلى وينمو جزئيا من خبرات الفرد الثخصية ولكنه ينأثز بدرجة بالغة بالتقييمات

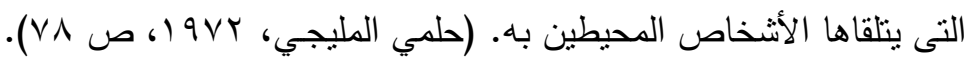

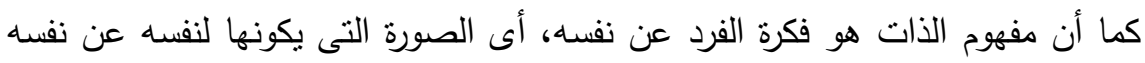

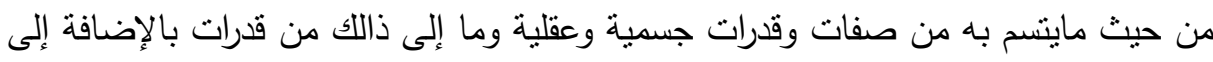
القيم والمعايير الاجتماعية وهو عامل هام فى توجيه السلوك ورسم مستوى الطموح. (محمد

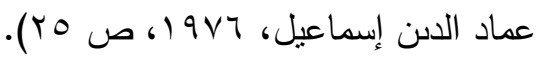
ونأنى هنا إلى مفهوم صورة الآخر والذى يعبر عن العملية السلوكية الإنتقائية الإختيارية الهادفة والتى تتأثر بالخبرة السابقة حيث يقارن فيها الفرد بين مفهومه عن ذاته ومفهومه عن ئن

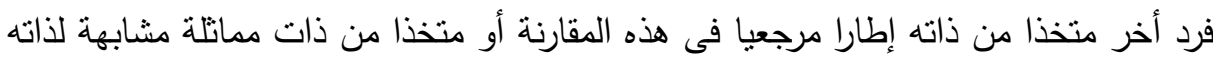

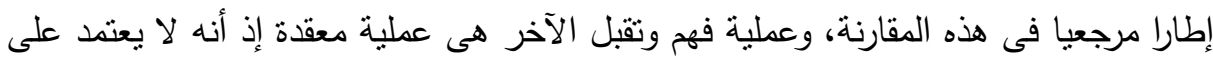

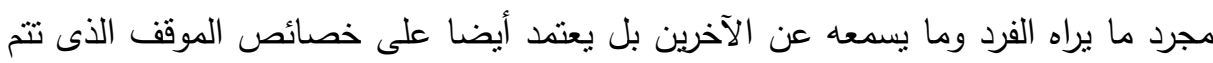

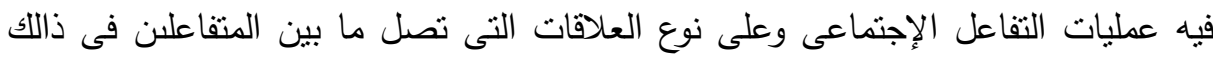
الموقف، فالإنسان كائن إجتماعي لا يسنطيع الحياة بمفرده وهو دائما في حاجة إلى التواصل

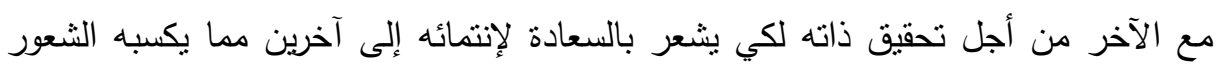

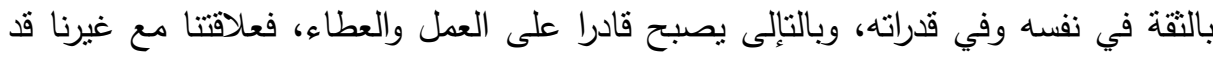

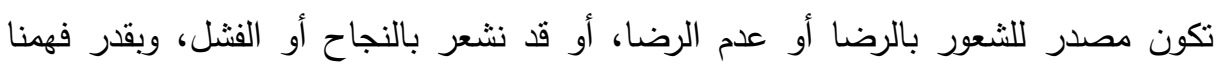

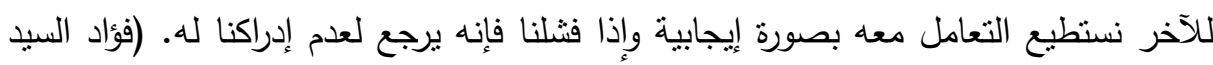


والأن نأنى الى العنصر البشرى الأساسى لهذا البحـث ألا وهم فئة (الأحداث

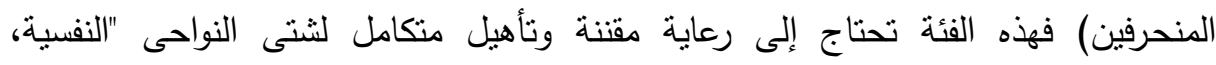

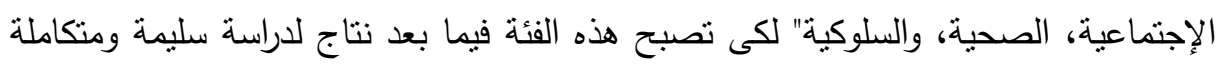

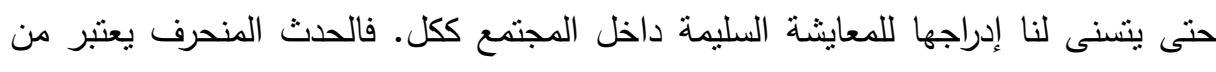

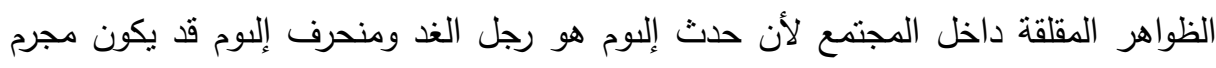

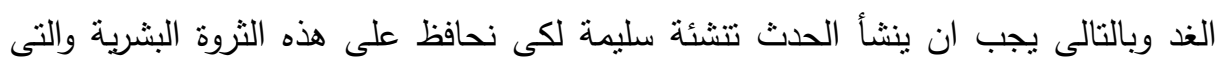

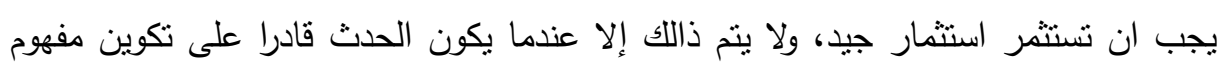

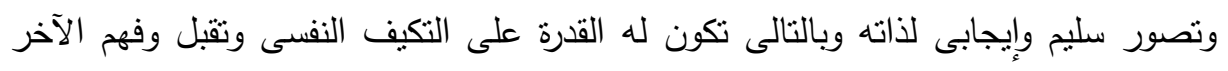

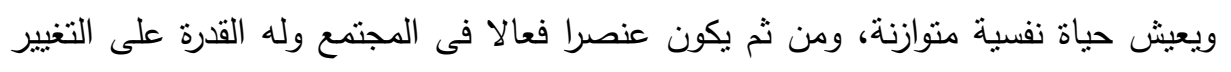

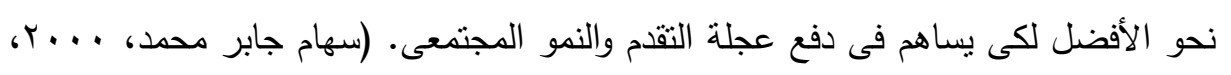

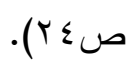

وتعتبر مؤسسات الأحداث الهنحرفين هى أولى محطات تأهيل ونمو الحدث "النفسى

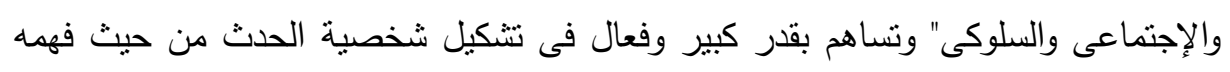

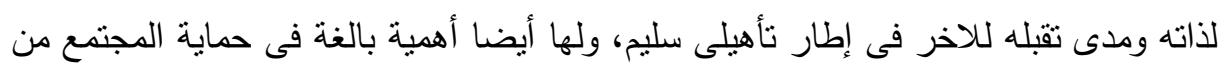

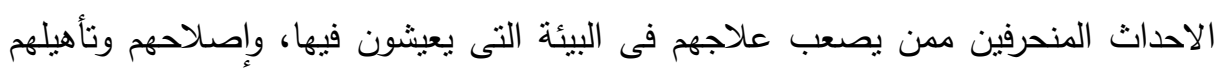

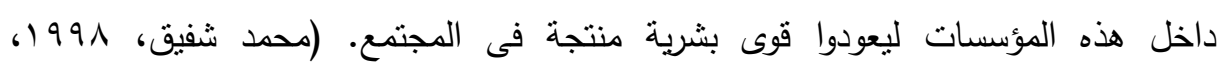

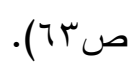

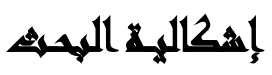

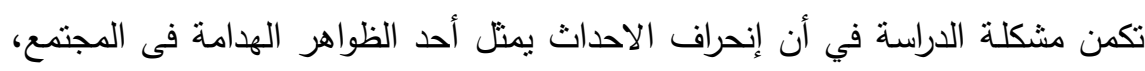

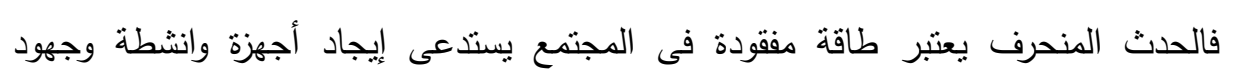

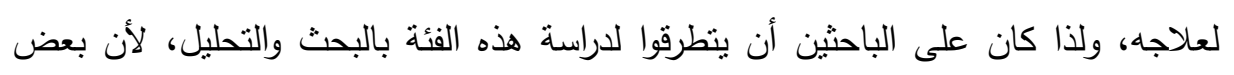

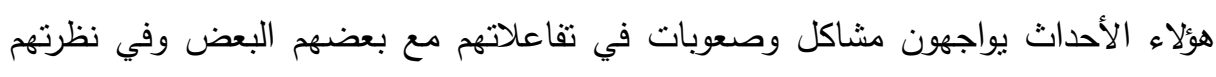

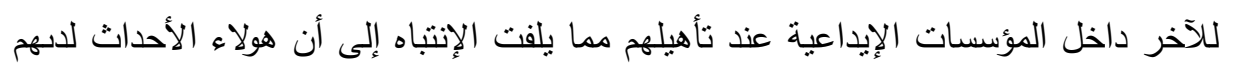


مشكلة في نظرتهم لذواتهم وللآخر • (الجمعية المصرية العامة للدفاع الاجتماعي، ب991 ا، ص

وهذا ما استوقف الباحثين لدراسة مفهوم (الذات وصورة الآخر لاده)، فالذات: هى

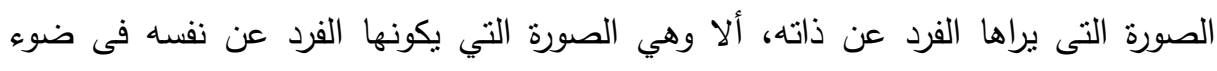

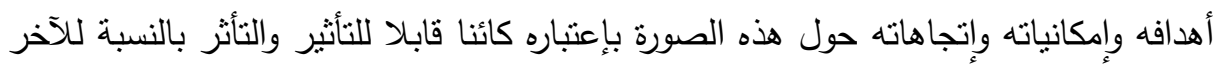
وكنتيجة لتجاربه مع الآخرين والطريقة التي يتعاملون بها معه إذا كانت بالسلب أو الإيجاب. أما صورة الآخر فهى عملية إدراك الفرد للآخرين تكمن في تكوين الإنطباعات والآراء والأحكام نحو الأشخاص الآخرين وأن مفهوم الذات الجيد لدى الفرد يؤدي إلى إدراك سليم للآخر

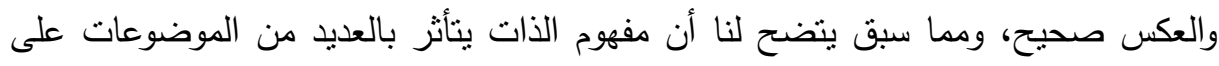

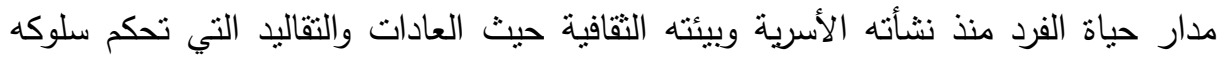
وبالتالي يؤثز بالطبع على نظرة الآخرين له ومن ثم يتكون مفهوم الذات لداده، ويقوم الفرد

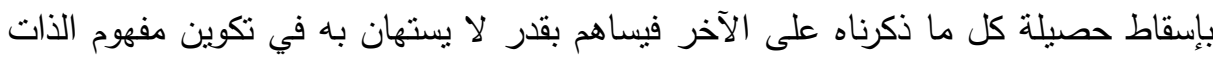
للده. وإنحراف الاحداث كمشكلة يتحقق في حالة جهل الفرد بخبراته الحقيقية وإنكارها، وتصرف بأساليب سلوكية غير موافقة للذات وكذاللك في حالة تكوين الخبرات التي لا تكون

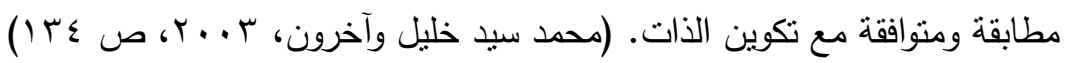

\section{تمساولاهي المهيف}

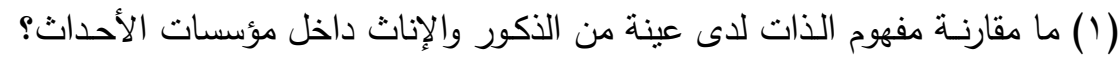

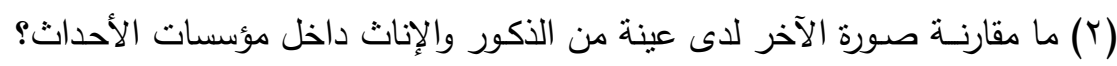

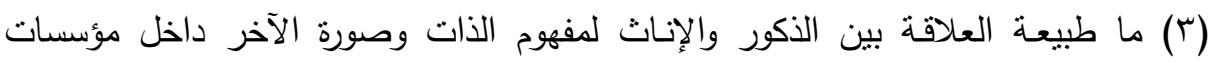

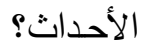




\section{أهسا اهت المهند}

الهـف العام للبحث: إلقاء الضوء على طبيعة الوضع الراهن لفاعلية ممارسات علم النفس البيئى والعلوم الإنسانيـة بمؤسسات رعاية الأحداث المنحرفين للوقوف على:مفهوم الذات وصورة الآخر لدى عينة من الأحداث المودعين داخل مؤسسات الأحداث.

وللوصول إلى تحقيق هذا الهذف العام يمكن صياغته فى مجموعـة من الأهداف الفرعية كالآتي:

(1) التعرف على طبيعة مفهوم الذات(البعد النفسي والإجتماعي) لدى الذكور والإناث داخل

$$
\text { مؤسسات الأحداث. }
$$

(r) التعرف على طبيعة صورة الآخر (البعد النفسي والإجتماعي) لدى الذكور والإناث داخل

$$
\text { مؤسسات الأحداث. }
$$

(r) الربط بين علاقة مفهوم الذات وصورة الآخر لدى الذكور والإناث داخل مؤسسات الأحداث.

\section{أهمية المهيه}

\section{الأهمية الاكاديمية (النظريــة):}

• تسهم هذه الدراسة في إلقاء الضوء على الأحداث الذين يقيمون داخل مؤسسات الأحداث وذالك لمحاولة ومعرفة كيف ينظر هؤلاء الأحداث لأنفسهم، ومدى قدرتهم على رؤية لإهية الآخر • يمثل كل من مفهوم الذات وصورة الآخر احد الاسباب الاساسية لتتكل المحور الرئيسي لثخصية الحدث. • يسهم هذا البحث في تحديد سلوك الحدث وتكيفه والوصول إلى الأهداف والغايات التي يسعى الفرد لتحقيقها. • يسهم هذا البحث في مواجهة المواقف المحرجة والمصاعب للحدث ويحسن من طرق

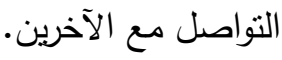


• ندرة الدراسات العربية (في حدود علم الباحثين)، التي تتاولت بالدراسة والتحليل مفهوم الذات وصورة الآخر لاى عينة من الأحداث المنحرفين.

الأهمية المجتمعية (التطبيقية): • الأهميـة التطبيقة تكمن فى مساعدة العاملين فى هذا المجال من الإستفادة بما تكثف عنه

$$
\text { الاراسـة من نتائج. }
$$

الإستفادة من الخبرات، والبرامج التأهيلية لمفهوم الذات للأحداث المنحرفين، وتطبيقها على نلى هذه الفئة من الأحداث من خلال الرعاية النفسية والتربوية والتأهيلية التي تقدم لهم. لهن.

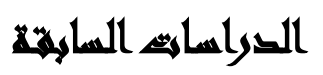

المحورالأول: الدراسـات السابقــة العربية التي تناولت بالبحث والتفسير والنتائج (مفهـوم الـات وصورة الآخر):

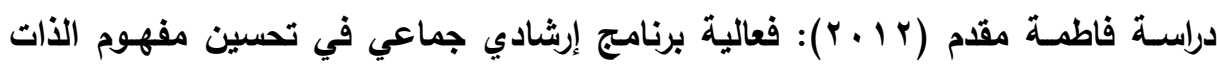

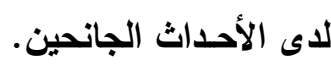
هدفت الدراسة إلى: إستقصاء فعالية برنامج إرشادي جماعي يستتد إلى النظرية العاطفية العقلانية السلوكية لألبرت إلس في تحسين مفهوم الذات للأحداث الجانحين.

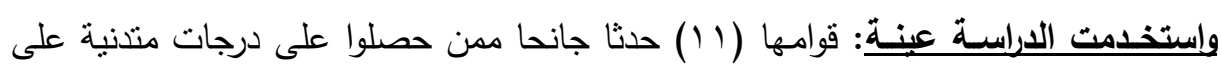

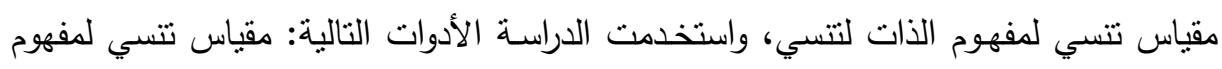
الذات، مقابلة لتحضير أفراد المجموعة التجريبية المشاركة في برنامج الإرشاد الجماعي.

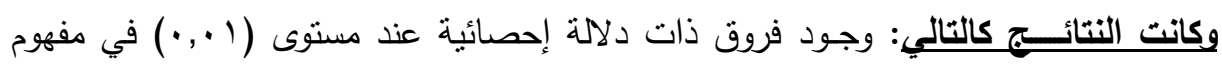
الذات لدى الأحداث الجانحين بين المجموعـة التجريبية والمجموعـة الضابطــة.

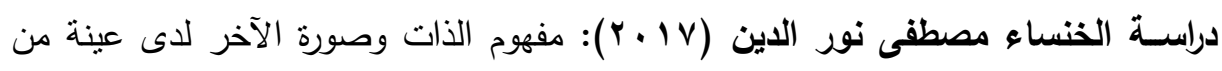

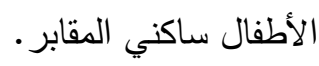

هــفت الدالسـة إلىى: الكثف عن العلاقة بين المنطقة السكنية (المقابر) ومفهوم الطفل لذاته وأيضا إدراكه للآخـرين.

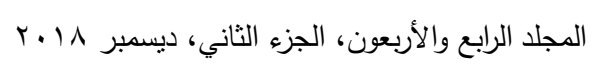


واعتمدت الدراسـة على المنهج الوصفي المقارن بالعينة. وتكونت عينة الدراسـة من

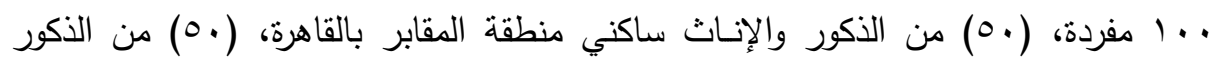

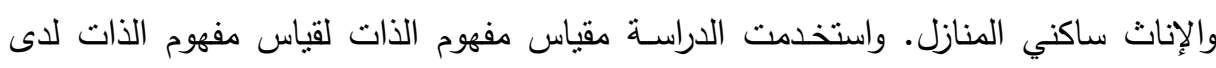
الأطفال ومقياس سمة الميل الاجتماعي. وتوصـلت نتائـج الدراســة إلمى: توجد علاقة إرتباطية بين الخصاعيائص الاجتماعية المتمثلة في مصدر الرعاية ومقياس مفهوم الذات. المحور الثـاني: الاراسـات السابقــة العربية التي تناولت بالبحث والتفسير والنتائج (الأحـداث المنحرفين ومؤسسات الأحداث المنحرفين)

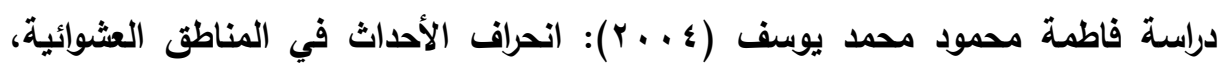

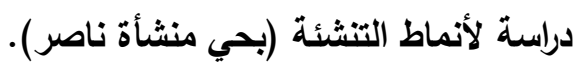

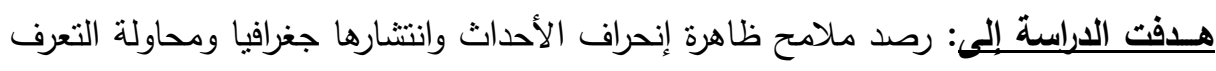

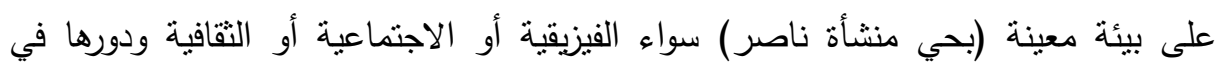

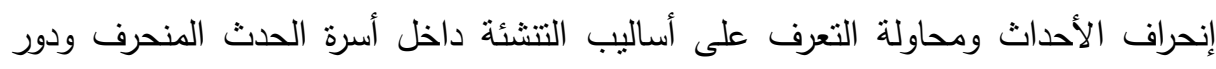
الجماعات الأولية في تتشئة الحدث المنحرف والتعرف على دور مؤسسات المجتمع المحلي في تتشئة الحدث المنحرف. واعتمدت الدراسة على منهج المسح الاجتماعي الثامل. وتكونت عينة الدراسـة من

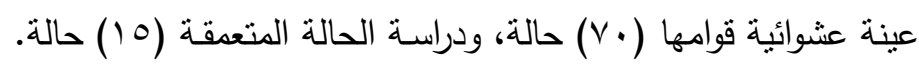

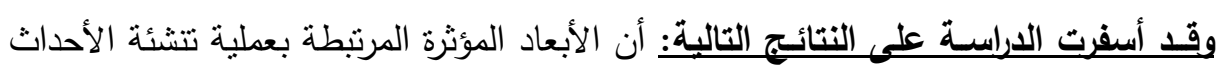

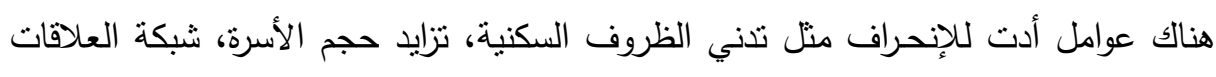
داخل الأسرة، طبيعة علاقة الحدث بالأم، عدم الاستقرار الأسري، طبيعة السلطة واتخاذ

دراســة منى طاهر على (^ . . ץ): تقويم البرامج التربوية لمؤسسات الأحداث الجانحين في ضوء احتياجاتهم التربوية. هدفت الاراسة إلى: تحديد الإحتياجات التربوية للأحداث المودعين بمؤسسات رعاية الأحداث

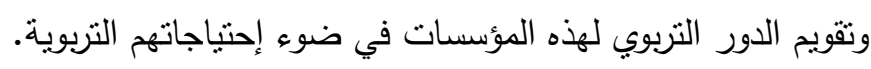

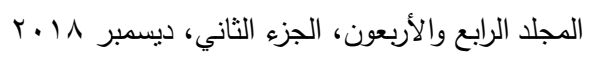


وتكونت عينة الدراسة من V مؤسسات ممثلة في نظامها وأسلوب عملها لبقية المؤسسات

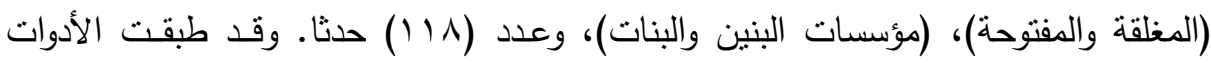

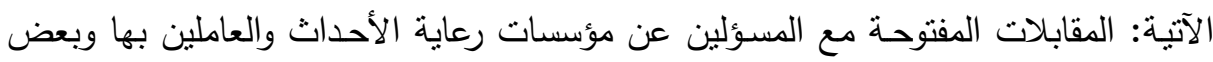
المتطوعين؛ الملاحظة؛ إستمارة المقابلة. وكانت نتائج الارلسة كالآتي: أن أكثر من نصف أفراد عينة الدراسة قد سبق لهم الإلتحاق بالمدارس النظامية وسبق لهم العمل قبل دخولهم المؤسسة، مما يعني أن باقي أفراد العينة

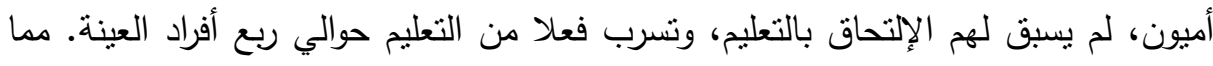

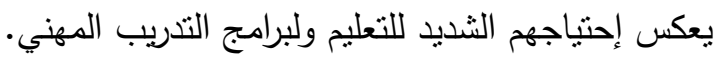
المحور الثـالث: الاراســات السابقــة الأجنبية التي تناولت بالبحث والتفسير والنتائج (مفهوم الأات، وصورة الآخر): (2005) - Sabir - Owens - Sahasin- Cecelia دراسة هــدت الدراســة إلى: بحث العلاقة بين ضبط الذات والأحداث الجانحين والآثار السلبية للتكيف الإجتماعي. وتكـونت عينـة الدراسـة من مجمـوعة من الأحداث البيض والسود. وإستخدمت الدراسـة الأدوات الأتبـة: مقاييس ضبط الذات؛ تحلـيل الإختلافات الجنسـية. وأثـــارت نتائسـج الدراسـة إلى الى وجود علاقة إيجابية بين ضبط الذات والتكيف الاجتماعي. ارتفاع في مستوى تقدير الذات عند الأحداث البيض عن الأحداث السود. وجود علاقة إيجابيـة بين الجنوح وتقدير الذات. :Hoshi - Akemi - Evelyn (2001) دراسة هدفت هذه الدراسة إلى: فحص تقديرات الذات عند الحدث الجانح في مدننة سلزبورج في - داري

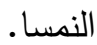

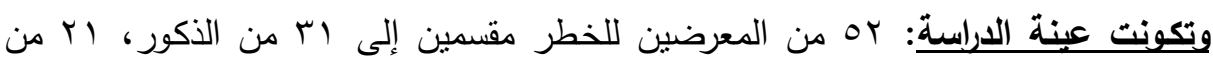

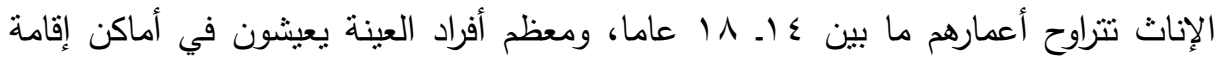
مؤسسيـة بعيدا عن أسـرهم.

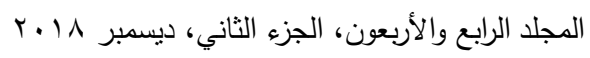


واستخـمت الدراسـة الأدوات الآتيـة: قائمة القياس النفسي؛ المقابلات المباشـرة.

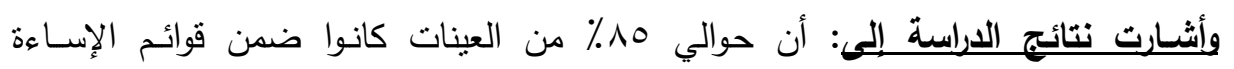

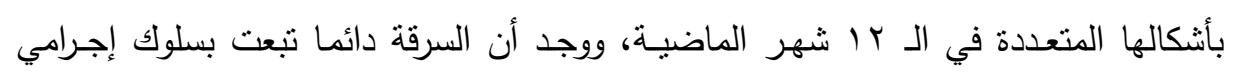
وعنف وتخريب وإدمان. المحور الرابع: الدراسـات السابقـة الأجنبية التي تتاولت بالبحث والتفسير والنتائج (الأحداث المنحرفين، ومؤسسات الأحداث المنحرفين) دراسـة 2005 Monell - Jack Santiago: هونس هدفت الدراسة إلى: إكتشاف المشاكل الاجتماعيـة المبكرة التي نسهم في جنوح الأحداث والعودة إلى الجريمـة فئة

وتكونت عينة الدراسة من: V10 حدثا كانوا محبوسين في مؤسسة كاليفورنيا الإصلاحية أعمارهم من Vا ـ 19 عاما. واستخدمت الدراسـة الأدوات الآتيـة: السجـلات الأرشيفية الموجودة في محاكم الأحداث. وأثشارت نتائج الدراسة إلى: أنه توجد علاقة قوية بين المشكلات الاجتماعية المبكرة مثل: (الممارسات الأسرية غير السوية، إمتداد مشاركة الأطفال في الجريمة، كيفية الخبرات الإرشادية أثناء حبس الثباب)، والمشاركة في أنشطة إجرامية في الطفولة وفترة الإرثـاد

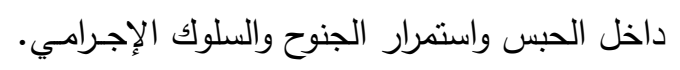

\section{همطلحاهي الههيه}

أولاً: مصطلح الذات (Self): إن الذات نستخدم بمعنيين مختلفين فهي تعرف من ناحية أنها إتجاهات الثخص ومشاعره نحو نفسه، ومن ناحية أخرى تعتبر مجموعة من العطليات

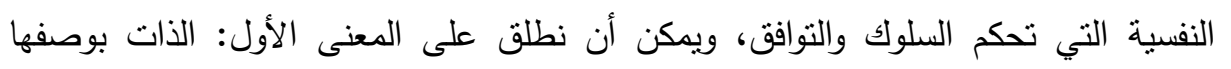
موضوع (Self as Object) حيث يدرك الثخص مشاعره ومدركاته وتقييمه لنفسه بوصنفه النئ موضوعا، وبهذا المعنى تكون الذات فكرة الثخص عن نفسه. ويمكن أن نطلق على المعنى

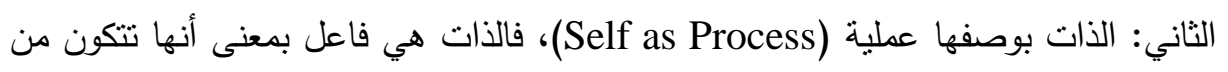

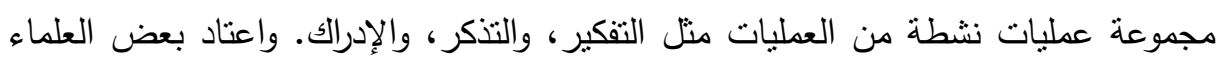

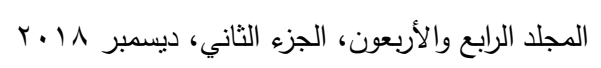


إستخدام تعبير الأنا (Ego) عندما يريدون الإشارة إلى مجموعة العمليات النفسية وأن يحتفظوا

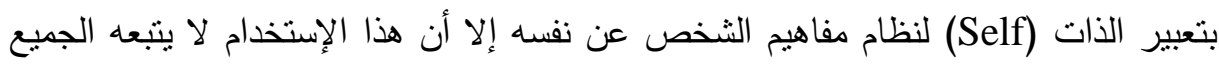

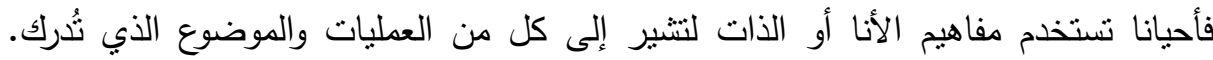

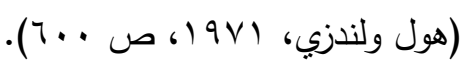
التعريف اللغوى لمصطلح الذات كما ورد فى بعض المعاجم العربية:. يقال فى الأدب نقد ذانى بما يفيد آراء الثخص وانفعالاته، وهو خلاف الموضوعى، ويقال جاء فلان بذاته أي وردي بعينه ونفسه، ويقال عرف من ذات نفسه أي بمعنى سريرته المضمرة وجاء من ذات نفسه أي

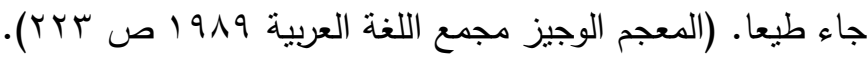
التعريف الاصطلاحى للأات: حيث يعنى مصطلح الذات جانب الثخصية الذى يتكون من مفهوم الفرد عن نفسه، وتعد طريقة إدراك الثخص لنفسه محصلة لتجاربه وخبراته مع الآخرين ولطريقة تصرفهم نحوه، ولإططلاع الذى يدركه من نظرتهم إليه، وتتطور الذات وتتمو خلال

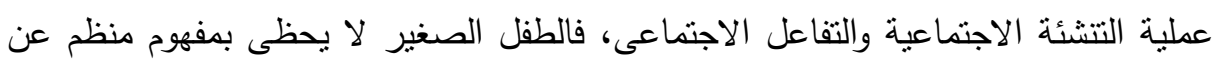

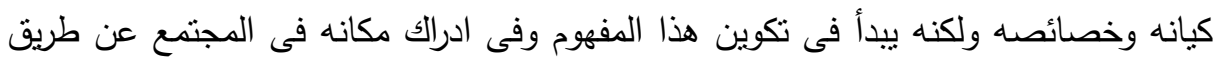
استشعار تقديرات الآخرين له. وفيما يلي يعرض الباحثون بعض التعريفات العربية والأجنبية التي تتاولت مفهوم الذات بالبحث والدراسة: التعريفات العربية للاتات: يُعرَف حامد زهران الذات: بأنها تكوين معرفى منظم ومتعلم للمدركات الشعورية والتصورات (Construction) والتقييمات الخاصة بالذات يبلوره الفرد ويعتبره تعريفا نفسيا لذاته ويتميز هذا التعريف بأنه يركز على المدركات الثعورية للفرد والتي تلعب دورا كبيرا في تحديد مفهومه عن ذاته، ويتكون مفهوم الذات من أفكار الفرد الذاتية المنسقة المحددة الأبعاد عن العناصر المختلفة لكينونته الداخلية أو الخارجية، وتتشل هذه دأه العناصر المدركات والتصورات التي تحدد خصائص الذات كما نظهر إجرائيا في وصف الفرد لذاته كما يتصورها هو "مفهوم الذات المدرك" (percieved self concepts)، والمدركات والتصورات التي تحدد الصورة التي يعنقد أن الآخرين في المجتمع يتصورونها، والتي ينمنلها

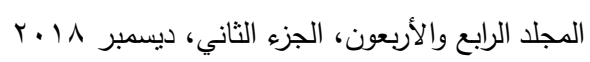


social self "الفرد من خلا التفاعل الاجتماعي مع الآخرين "ففهوم الذات الاجتماعي

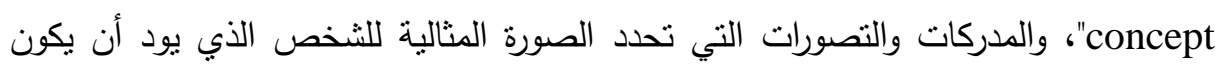
"ideal self concept"

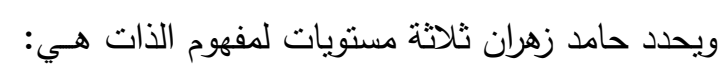

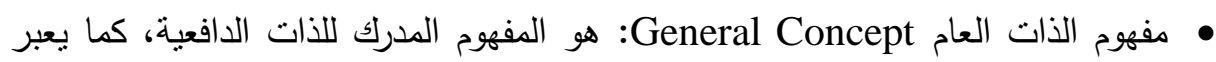
عنه الثخص نفسه، ويضم هذا المفهوم عددا من مفاهيم الذات مثل (مفهوم الذات

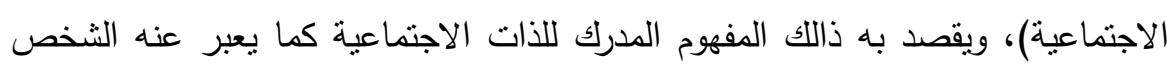

• مفهوم الذات المكبوتة Repressed Concept: وهو المفهوم الذي يتضمن أفكار الفرد المهددة عن ذاته، والتي نجح دافع تأكيد وتحقيق وتعزيز الذات في تجنيد ميل الدفاع؛ فدفعت به إلى اللاشعور ، ويحتاج التوصل إليه إلى التحليل النفسي.

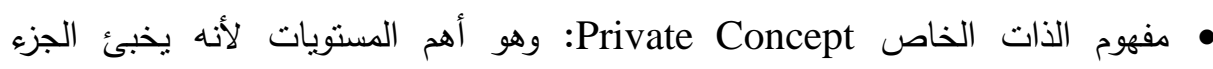
الثعوري السري الثخصي من خبرات الذات، ومعظم محتويات مفهوم الذات الخاص أله محرمة، أو محرجة، أو مخجلة، أو بغيضة، أو غير مرغوب فيها إجتماعيا، ويعتبر مفهوم الذات الخاص بمثابة عورة نفسية لايجوز إظهاره أمام الناس (حامد عبد السلام زهران،

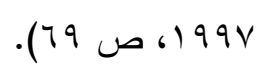

التعريفات الأجنبية للذات: الذات عند فرويد (Freud):. هى الأنا التى تتكون من مجموعة

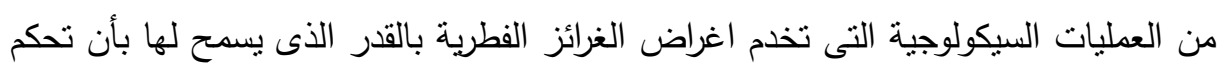

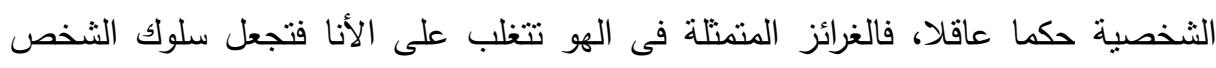

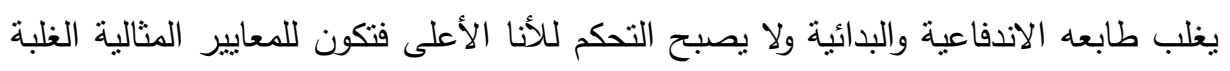
بحيث يجد الثخص نفسه فى احباط مستمر قد ينتهى به الى الثعور بالاكتئاب والفشل.

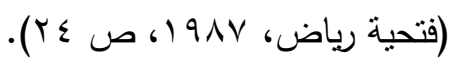

ويعرف (ميشيل رينتارد Mishel Richard): مفهوم الذات انها الصورة التى يكونها الفرد عن نفسه (أنا شخص اعنمادى - أنا ذكى - أنا جميل - أنا منطوى ...إخخ) فنحن نكون انطباعا عن ذواتتا كما نكون انطباعا عن الآخرين. (Mishel. R., 1981, P. 494).

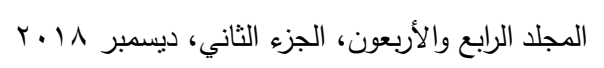


ويلعب مفهوم الذات دورا كبيرا في تأثيره على إنساق السلوك الإنساني، وفي تتكيل

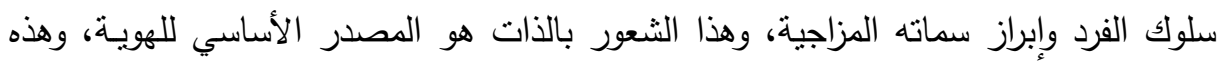
الهوية تتضمن مفهوم الذات، ويعد البحث في موضوع الذات صعبا وذالك لعدد من المبررات التي تصب في إرتباط موضوع الذات بالنواحي الذاتية المتعلقة بالفرد.

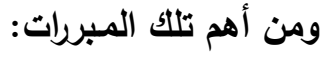
( ) تعود صعوبة البحث في الذات إلى تشعبه وارتباطه بالكثير من المشكلات الفلسفية العميقة

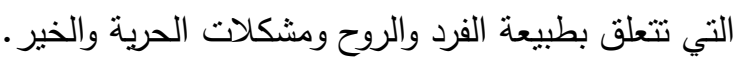
r بالرغم من وجود معرفة تامة عن الذات لدى كل فرد فإن هناك أنثياء لايسنطيع الجزم بمعرفتها عن ذاته، فليس هناك حدود فاصلة بين ما له علاقة بالذات وما ليس لله علاقة بله

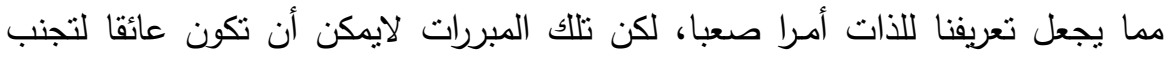
دراسة موضوع الذات وهذا ما يؤكده" اولبورت" ويقدم أسباب تلفت النظر إلى أهمية البحث لنث

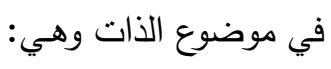

أ) أن المعيار الوحيد الصادق لوجودنا الثخصي ووحدتتا يكمن في إحساسنا بالذات وتجنب هذا الإحساس يعني استبعاد جوهر المشكلة. ب) أن نظريات التعلم والدوافع والنمو لايمكن أن تكون كاملة وصحيحة مالم تميز لإنئ بين ما يكثف عن الذات في الثخصية ومالا يكثف عنها. ج) هناك صعوبة في حل المشكلات الفلسفية الكبرى بين الباحثين، إلا أن علماء النفس ينبغي

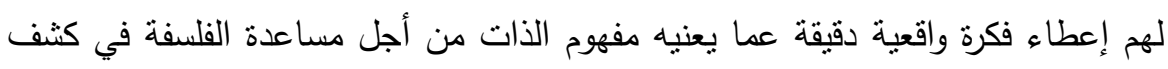

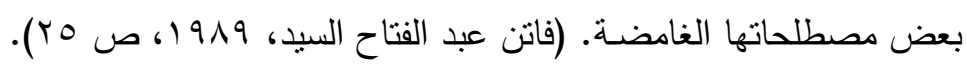

تاريخ تطور دراسـة الذات: الحديث حول موضوع الذات له بدايات تعود إلى الفلسفة اليونانية القديمة إذ كانت أحد المفاهيم للوجود اللامادي الذي وصفه سقراط بأنه "الروح"، وهي إثنارة لها

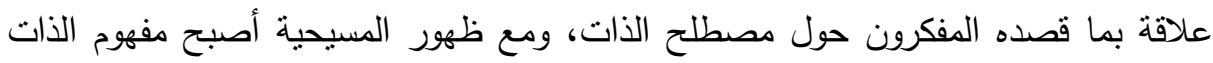
جزءا من التفسيرات الدنية وعلم الفقه وابتعد عن إستخدامات التفكير العلمي، ولقد نكررت

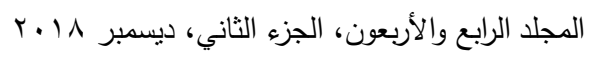


كلمة الذات في القرعان الكريم (•r) مرة ويشمل ذاللك ما اتصل بها من ضمائرها ونحوها، وتأني في القرءان الكريم على وجهين:

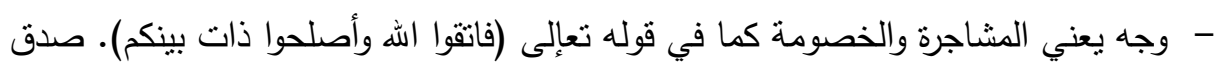
الهه العظيم، سورة الأنفال آية (1).

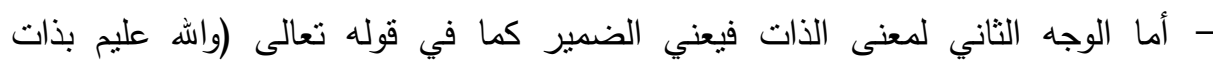

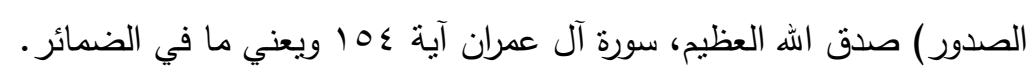
ونجد في المجمع الوجيز تحت مادة "ذات" ذات الثيء حقيقته وخاصته والذات (النفس الهن

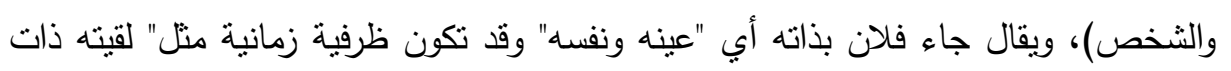

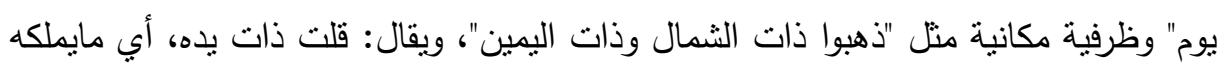

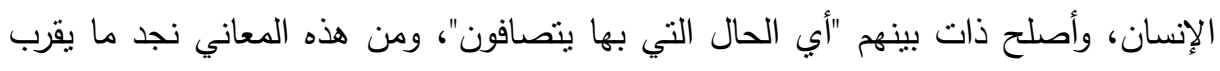

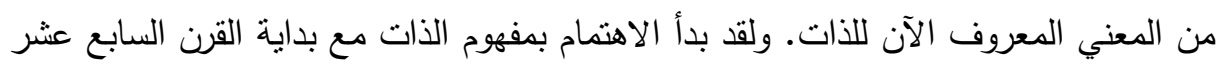

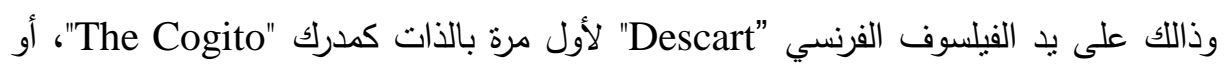

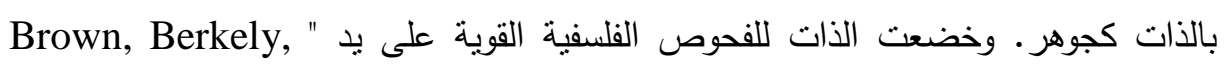

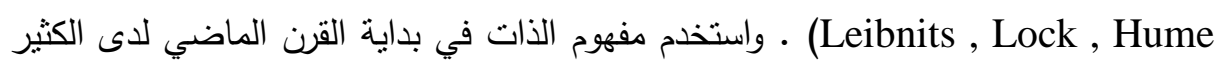

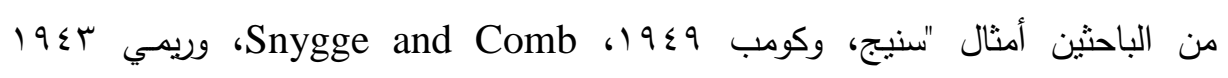

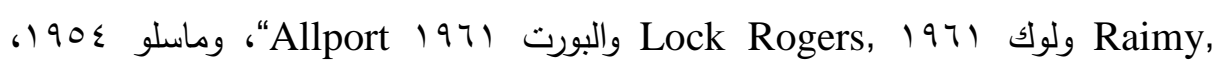
Maslow. وقد إرتبطت البداية العلمية لدراسة الذات بجهود العالم "وليم جيمس" في كتابه

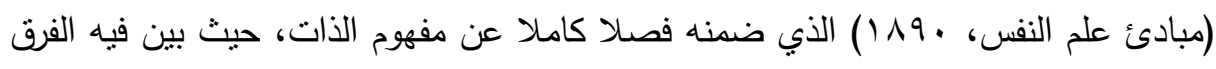

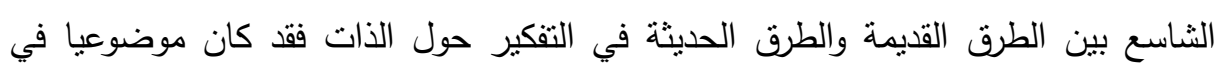
معالجته للموضوع. وتعد إسهامات (وليم جيمس .William, J)، نقطة تحول في دراسة مفهوم

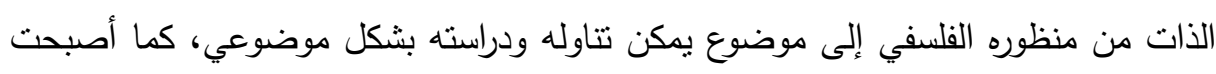
آراؤه في هذا المفهوم فيما بعد مرجعا خصبا للعديد من المنظرين في دراساتهم لـفهوم الذات.

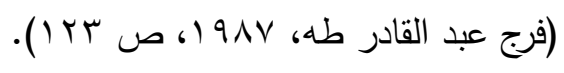


تصنيفات مفهوم الذات: الواقع انتا جميعا نعبر عن ذوانتا بتعبيرات سهلة مبسطة سواء أكان

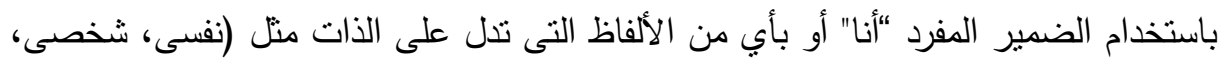

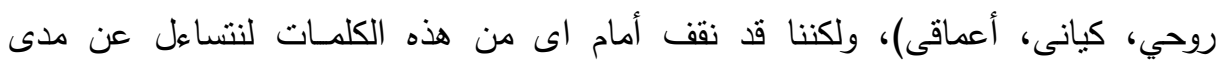
مطابقتها لمكونات الذات الإنسانية بالفعل ومدى تمشيها مع التكيف الداخلى للنفس البشرية. وهنا يعجز البيان ويترك الإنسان فى حيرة من أمره.

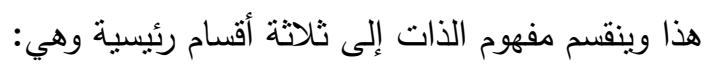

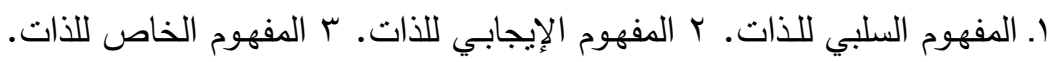

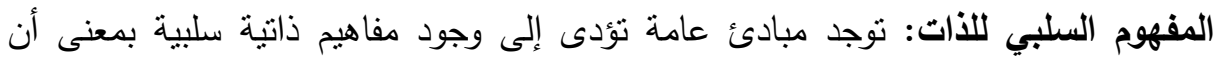
الثخص الذى يكون لديه مفهوم ذات سلبى يمكن وصفه عامة بأنه ذاللك الثخص الذصى يفتقر

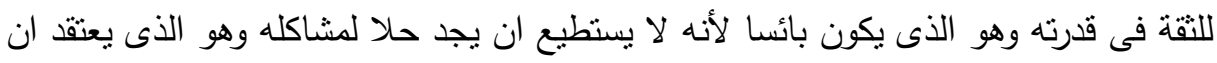

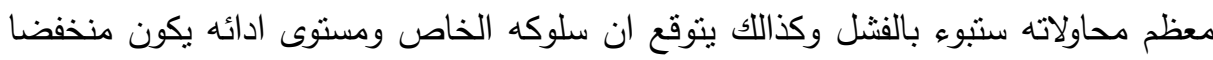
جدا. والواقع إن من يكون لنفسه مفهوما سلبيا كثثرا ما يكثف عن هذا لها المفهوم من اسلوب حديثه أو تعاملاته أو تصرفاته الخاصة أو من تعبيره عن مشاعره تجاه نفسه أو تجاه الآخرين

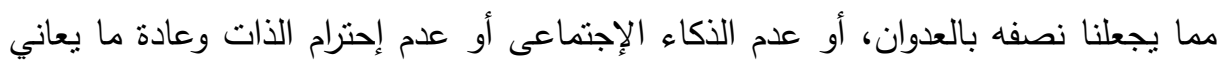
منل هؤلاء الأفراد من نوعين من السلبية: (الأولى): ويظهر فى عدم القدرة على التوافق مع العالم الخارجى الذى يعيشون فيه حيث تسمع أيا منهم يعبر عن ذالك (بأنه ليس على مستوى الآخرين)، أو انه محمل بالمشاكل والهموم، أو أنه يشعر بعدم الاستقرار النفسي وعدم الإطمئنان في حياته.

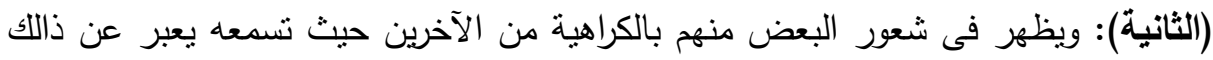

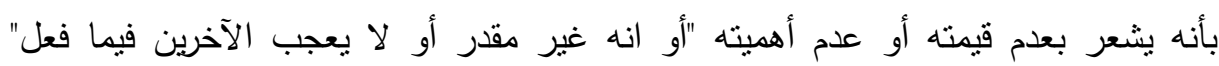

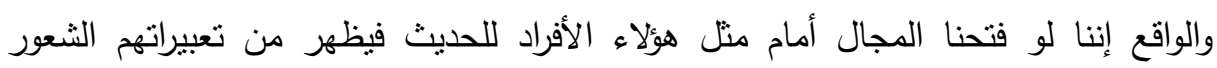

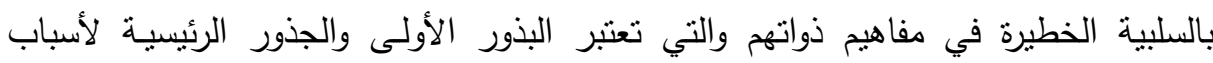
الإنحرافات والمشكلات السلوكية.

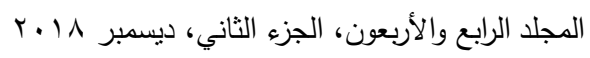


المفهوم الإيجابى للأات: ويتمنل فى تقبل الفرد لذاته ورضائه عنها، حيث تظهر لمن يتمتع بمفهوم ذات إيجابى صورة واضحة ومتبلورة للاتات (Self-Image) يلمسها كل من يتعامل

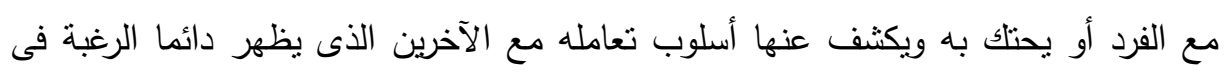

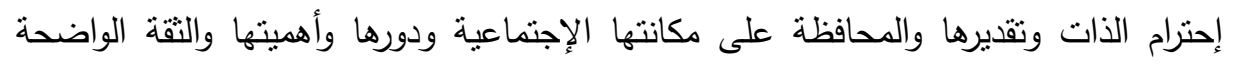

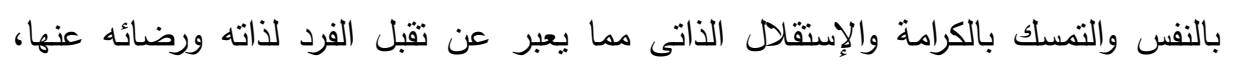

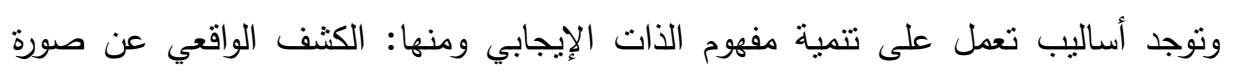

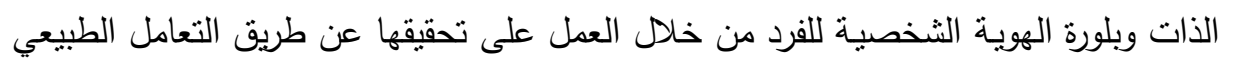
السوي مع الفرد وبتمكنه من التعبير الصريح عن الرأي وبمساعدنه في إنخاذ القرارات اللازمة فئية

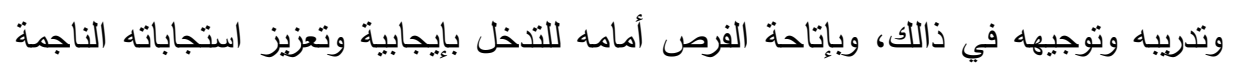
ومبادراته الصحيحة، والعمل على استشعاره بإستمرار الحب والعطف والحنان والإحترام والثقة

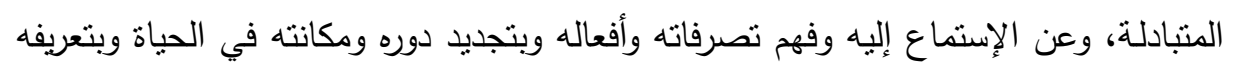

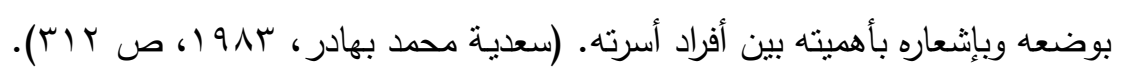

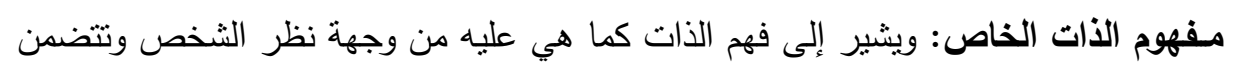

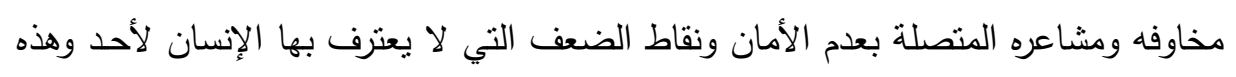

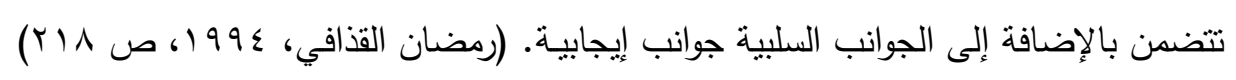

(التعريف الإجرائي للذات): - Operational Definition)

(1) إن مفهوم الذات تكوين معرفى يكونه الفرد عن ذاته من خلاد مدركاته الثعورية وتصوراته وخبراته المكتسبة من علاقاته بالآخرين.

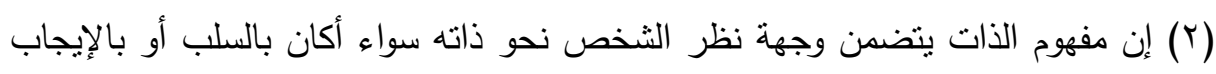

$$
\text { وبمعنى آخر تقييم الفرد لنفسه كما يراها هو . }
$$

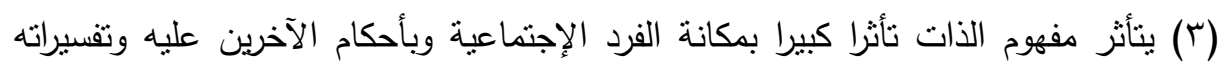
لإستجاباتهم.

(§) يشير مفهوم الذات اعتباره مجموعة من العمليات السيكولوجية التى تحكم السلوك والتوافق فهى نشاط موحد مركب للإحساس والتذكر والتصور والإدراك والحاجة والثعور والتفكير وبهذا تعتبر الذات عملية تتضمن مجموعة عمليات نفسية منكاملة. 
(0) إن الذات تساعد فى تكوين المعايير الخلقية وتتحقق هذه المعايير من خلال سلوك الفرد وتقبل المعايير الموجودة فى المجنمع. (7) أن مفهوم الذات متعلم من خلال خبراته. ( أن مفهوم الذات ثابت إلى حد كبير إلا أنه يمكن تعديلـه. (^) أن مفهوم الذات يمكن قياسه من خلال خبرة الفرد بالواقع. ثانياً: مصطلح صورة الآخر (Other Image):. ويشير مصطلح صورة الآخر إلى بلى "العمليات التى يعلم عن طريقها الطفل ويفكر فى الآخرين، وفى سماتهم الثخصية المميزة وصفاتهم، وحالاتهم الداخلية". وهى العمليات التى تتشكل بها الإنطباعات والأفكار عن الأفراد الآخرين، وتتضمن أحكاما ذاتية، واستدلالات تذهب إلى ما وراء المعلومات الحسية. كما يشير إلى العملية المنطوية بفهم الآخرين، وأيضا الممارسات التى تؤدى إلى توليد إستجابة لمثير

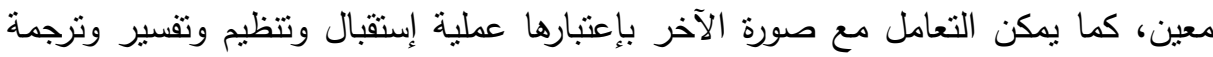

المدخلات التى ترد إلى الفرد من البيئة المحيطة. (Night, R. M., 1992, p. 214). يذكر سيكوند وبكمان (Second P. \& Beckman) صورة الآخر بأنها: العملية التى تتتكل

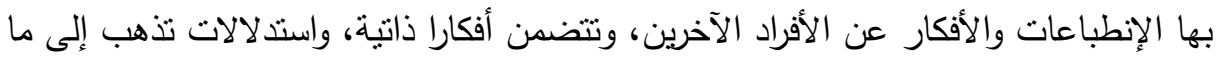

وراء المعلومات الحسية المباشرة. (Second, P. \& Beckman, Cal, 1964, p. 61). وهناك تلازم بين مفهوم الذات ومفهوم الآخر فاستخدام أى منها يستدعي تلقائيا حضور الآخر وهذا التلازم على المستوى المفاهيمي هو تعبير عن طبيعة الآلية التى ينم وفقا لها لهاتيل

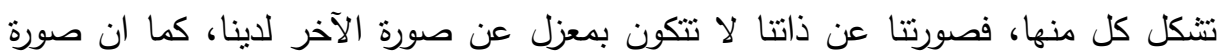

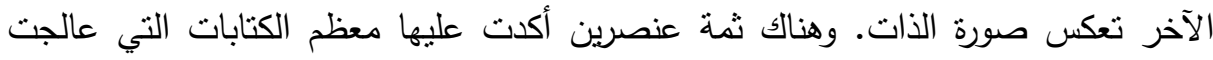
(مفهوم الذات والآخر)، العنصر الاول (معرفي)، والعنصر الثاني (تقييمي)، وكلا العنصرين

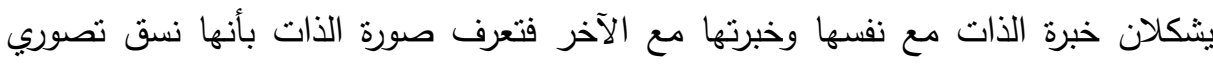

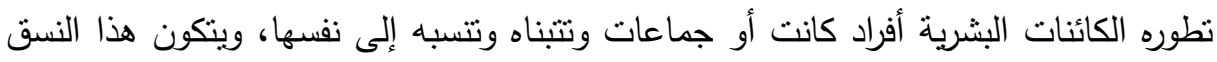

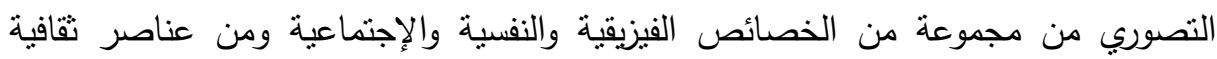
كالقيم والاهداف والقدرات التي يعتقد الافراد وتعتقد الجماعة انها تتسم بها، أما صورة الآخر

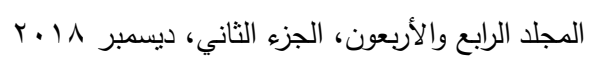


عبارة عن مركب من السمات الاجتماعية والنفسية والفكرية والسلوكية التي ينسبها فرد ما أو جماعة إلى آخرين. وهنا نثير إلى أن مفهوم الذات وصورة الآخر قابلتان للتعديل والتغيير رغم ما يبدو عليها من نبات واستاتيكية كما أنه قد يختلط فيها الواقعي بالمنالي وينداخل فيها

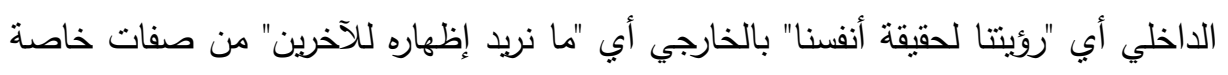

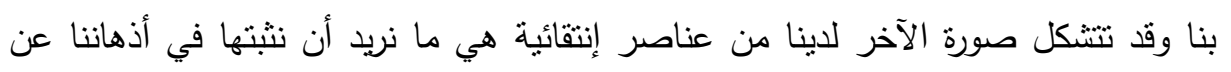

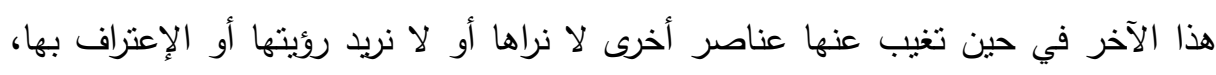

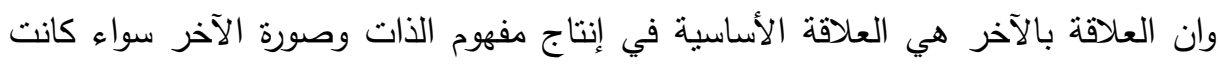
تلك العلاقة بين جماعات أو طبقات أو شعوب. (فتحي أبو العينين تحرير الطاهر لبيب،

\section{ثالثاً: مصطلح الأحداث المنحرفين:}

الحدث في المعجم الوجيز: الصغير السن والأمـر الحادث النكر غير المعتاد (نكثف به عن

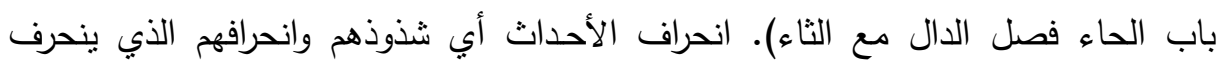

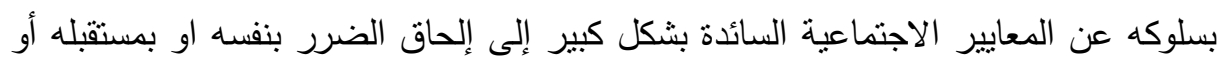

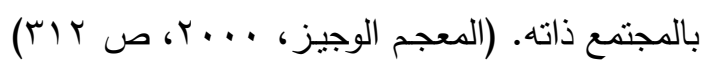

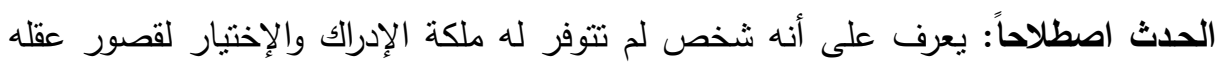

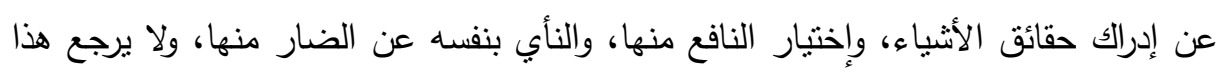

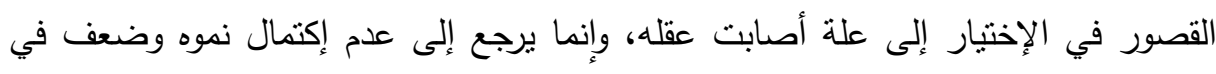
قدرته الذهنية والبدنية بسبب وجوده في سن مبكرة ليست في إسنطاعته بعد وزن الأمور

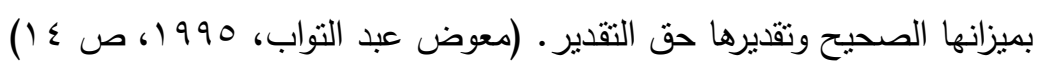
الحدث الجانح أو المنحرف: هو الثخص الذي لم يتجاوز الثامنة عشرة من عمره وقام بأفعال

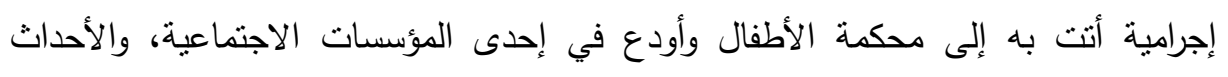

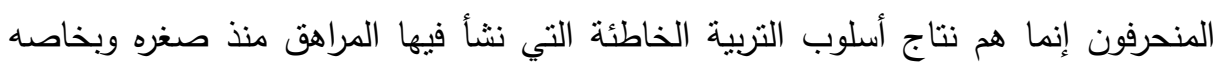
علاقته بأبويه وما يتبعها من حالات الصراع الأوديبية وإضطراب نحو الذات العليا وتفكلك فئك

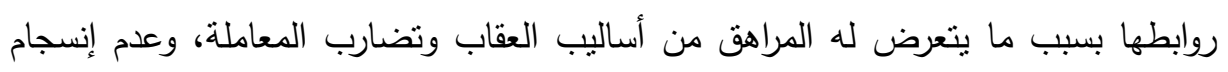

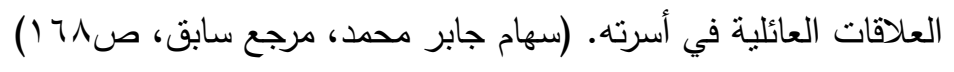

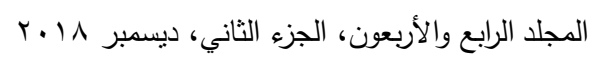


مفهوم الانحراف: يرى معجم علم الاجتماع أن "الإنحراف الاجتماعي" مصطلح يستخدم في

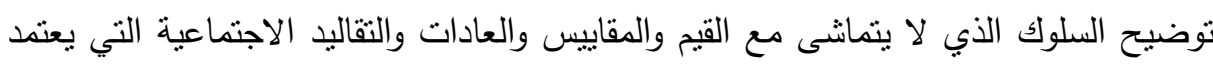
عليها المتمع في تحديد سلوك أفراده وهو سلوك غير وظيفي وشاذا يتتاقض مع الأحكام الاجتماعية والعرفية الضرورية لعملية التماسك الاجتماعي في النظام أو الجماعة. (المؤتمر

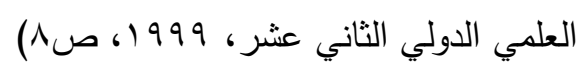

وعرَفته (منيرة العصرة) بقولها: هو موقف إجتماعي يخضع فيه صغير السن لعامل أو أكثر من العوامل ذات القوى السببية مما يؤدي به إلى السلوك غير المتوافق أو يحتمل أن يؤدي لهي إليه".

وقد قامت منيرة العصرة بتصنيف الأحداث المنحرفين في كتابها (إنحراف الأحداث ومشكلة العوامل) حيث صنفت الأحداث المنحرفين إلى الأصناف التالية: (أ) الأحداث المنحرفين. (ب) الأحداث المعرضون للإنحراف: وهم أربعة أقسام:

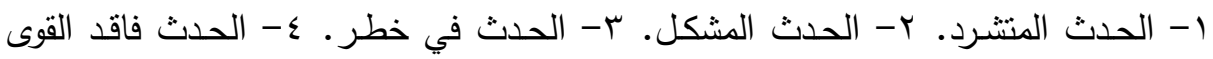
العقلية. كما قسَم (إنجلش وبيرسون) الأحداث المنحرفين إلى خمس طوائف: ا ـ الأحداث الذين يعانون من نقص عقلي.

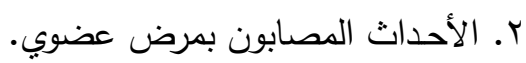
r. الأحداث ذوو الوظائف النفسية المختلفة. ع. الأحداث ذوو الشخصية السيكوباتية.

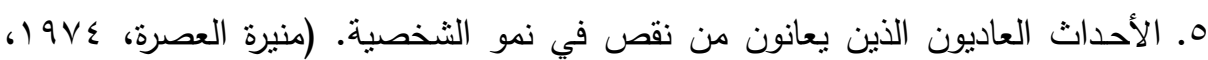
النظريات المفسرة لإنحراف الأحداث:

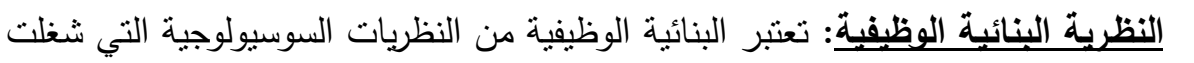
حيزا كبيرا في أدبيات علماء الاجتماع وخاصـة في بداية القرن العشرين واحتلت مكانة مرموقة بين نظرياته، وينظر أصحاب إتجاه البناء الوظيفي وعلى رأسهم (تالكوت بارسونز )

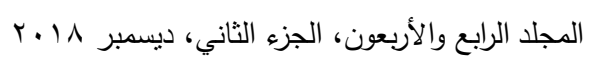


إلى المجتمع بإعتباره نسقا إجتماعيا (social system) مترابطا داخليا ينجز كل جزء من

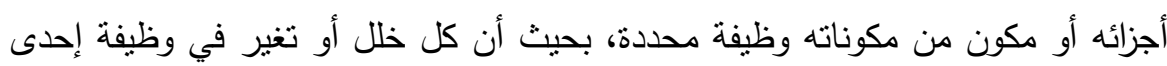
مكوناته يؤثر بالسلب في باقي أجزاء النسق، ويمكن إعتبار أن كل شيئ سواء كان كائنا حيا أو إجتماعيا أو فردا أو مجموعة على أنه نسق أو نظام، وهذاء النّاء النسق يتألف من أجزاء

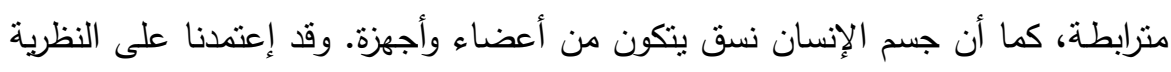
البنائية الوظيفية في تفسير مفهوم الذات وصورة الآخر لدى عينة من الأحداث المودعين داخل مؤسسات الأحداث، وهذا لان هذه المؤسسات خاصة برعاية وتأهيل الأحداث

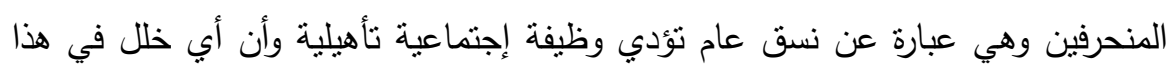
النسق العام يؤدي بالفعل إلى خلل في النظام كامل وفي إنحراف النسق، ولهذا عأنأني

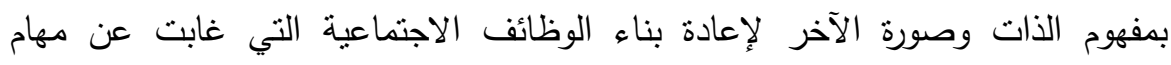

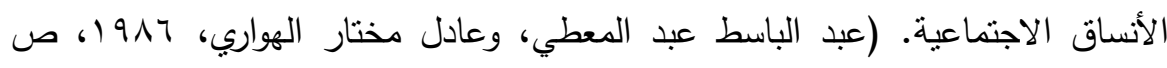

• نظرية الدور الاجتماعي: يهنم العالم (ماكس فيبر) بالدور الاجتماعي أكثر مما يهتم بأي

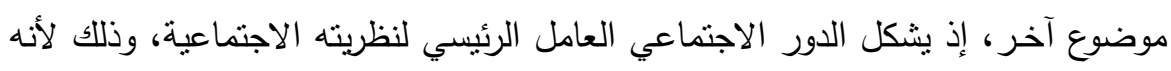

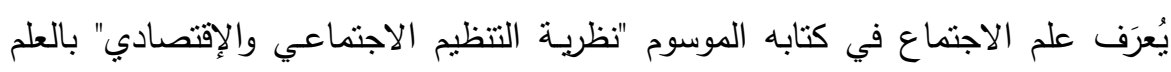
الذي يفهم ويفسر السلوك الاجتماعي، ويعني فيبر بالسلوك الاجتماعي أي نشاط أو حركة الأنة

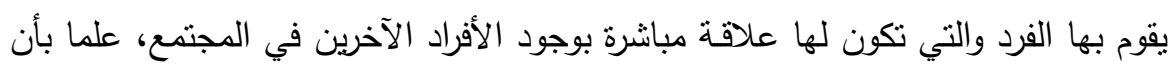

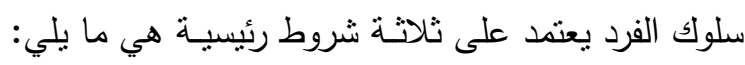
( ) وجود الدور الذي يشغله الفرد والذي يحدد طبيعة السلوك الذي يقوم به الفرد. r) إستعمال الرموز السلوكية والكلامية واللغوية المتعارف عليها من قبل الأفراد عند القدية القيام بالسلوك. r) وجود علاقة إجتماعية تربط شاغل الدور مع الآخرين عند حدوث السلوك.

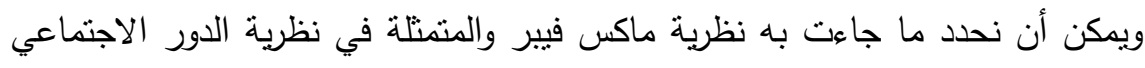
والتي تتفق في عدة نقاط مع مشروع بحثنا فيما يلي: 


$$
\text { ا ـ تقديم وترسيخ الأدوار التربوية عند الحدث المنحرف. }
$$

r r مساعدة الحدث على معرفة ذاته وأيضا على التواصل الفعال مع الآخرين.

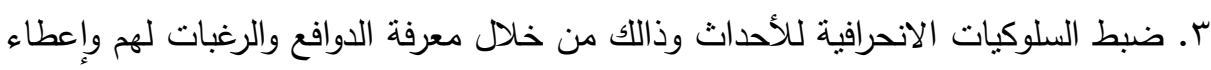
البدائل.

ع. تساهم وتعطي بُعدا تربويا ونفسيا وإجتماعيا من خلالها يمكن تحديد الأدوار وتضبط السلوكيات.

العلاج في مجال رعاية الأحداث المنحرفين: يهدف العلاج في مجال رعاية الأحداث المنحرفين إلى تتمية شخصية الحدث ومساعدته للإعتماد على نفسه ومواجهة مشكلاته، ويتضح في صورة العمليات والخدمات التي تنتهدف التأثثر الإيجابي في ذات الحدث أثل أو في ظروفه المحيطة لتحقيق أفضل أداء ممكن لوظيفته الاجتماعية أو لتحقيق أفضل إستقرار

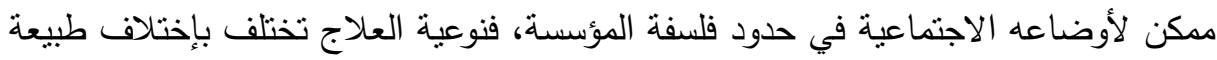

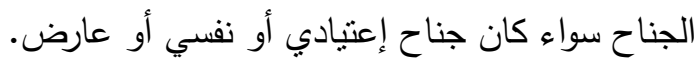

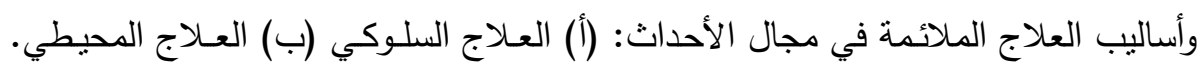
رابعاً: مصطلح مؤسسات الأحداث المنحرفيـن: المؤسسة: هى كلمة إنجليزية بمعنى "معهد أو منشأة" وهى نمط منتظم من سلوك الجماعـة وهى هيئة منظمـة قائمة فى المجتمع تعبيرا عن حاجة الناس إلى خدمات معينة لتمنل مسؤلية المجتمع نحو أفراده، وتؤكد أهية رعايتهم بجميع الطرق المختلفة.

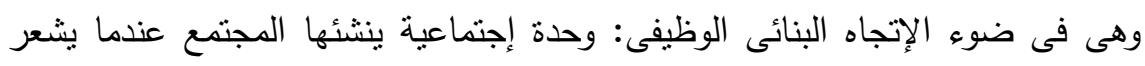

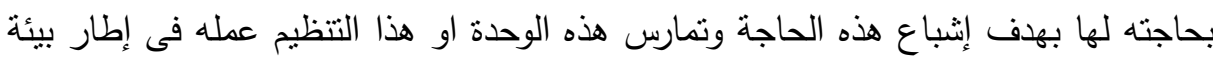

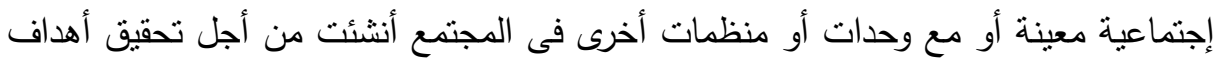
وتعرَف أيضا بأنها: مؤسسة علاجية تتبع وزارة الثؤون الاجتماعية، وتقوم بإعداد وتربية

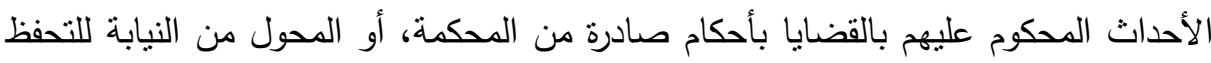

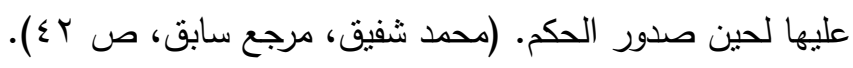

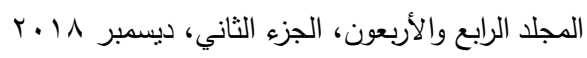


وتقوم مؤسسات رعاية الأحداث المنحرفين على تتفيذ الأهداف التالية:

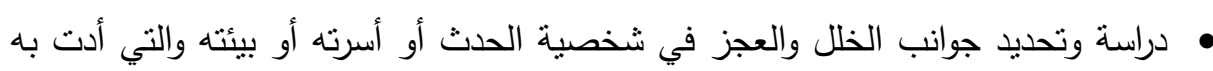
إلى الحالة الراهنة، والظروف الصعبة التي يعيش فيها. • مساعدة الحدث على التعرف على نواحي القوة والضعف في شخصيته.

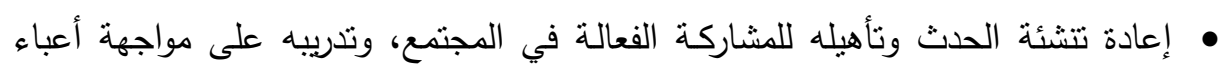
الحياة. • تقوية واستعادة قدرات الحدث لتحسين الأداء الاجتماعي وتحقيق التوافق النفسي والإجتماعي، وتقوية العلاقات والروابط مع الآخرين.

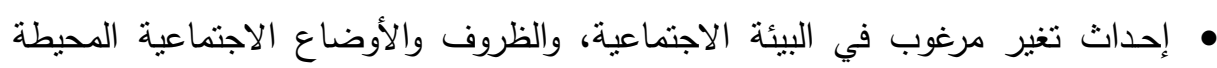
بالحدث وتخفيفها لتحقيق مستوى معيشة أفضل وحياة كريمة.

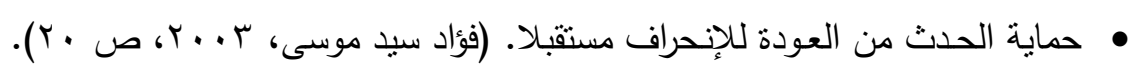

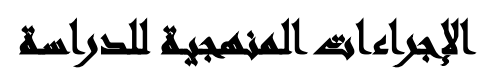

ويمكن عرض الإجراءات المنهجية للبحث الميداني على النحو التالي: Analytic Descriptive نوع الدراسة: هذا البحث يعتبر من الدراسات التحليلية الوصفية الإنية والتي تعتمد على أسلوب المسح الاجتماعي بالعينة والتي يمكن عن طريقها الحصول على دنى معلومات دقيقة تصور الواقع وتسهم في تحليله، ولأنها أنسب أنواع الدراسات ملائمة لطبيعة بلئل

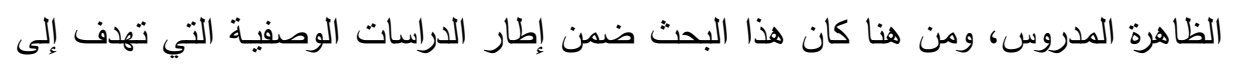
محاولة التعرف على مفهوم الذات وصورة الآخر لدى عينة من الأحداث (ذكور ، إناث) داخل مؤسسات الأحداث بالقاهرة الكبرى. ( عبد الباسط حسن، مرجع سابق، ص صل م1 (1) ).

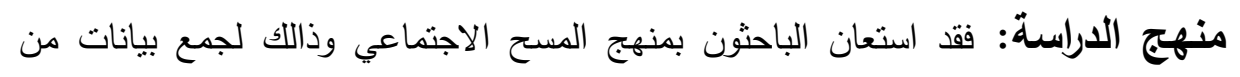
أعداد كبيرة من المبحوثين عن طريق الإتصال بمفردات مجتمع البحث سواء كان الإتصال لهال

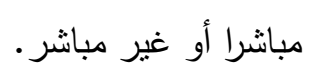
مصدر البيانات: المصادر الثانوية: حيث اتجه الباحثون في معالجة الإطار النظري للاراسة

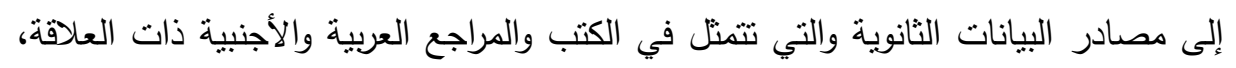
164

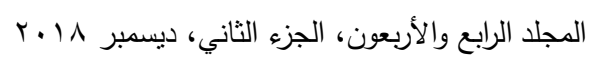


والدوريات والدقالات والتقارير، والأبحاث والدراسات السابقة التي تتاولت موضوع الدارسة، والبحث والمطالعة في مواقع الإنترنت المختلفة. المصادر الأولية: وتتمنل في جمع البيانات الأولية ميدانياً، وذلك من خلال استخدام استبيان

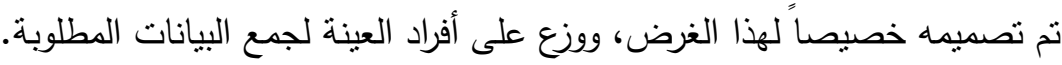
ادوات الاراسة: فى إطار هذا البحث استعان الباحثون ببعض الأدوات: •المقابلة المفتوحة: تعتبر المقابلة احدي أدوات جمع البيانات لذلك استعان الباحث بدليل المقابلة للحصول على البيانات الكيفية لتدعيم البيانات الكمية.

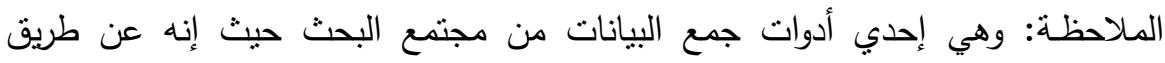
الملاحظة المقصودة وغير المقصودة يمكن جمع بيانات لا يمكن جمعها من الطرق الأخرى. - (المان. مقياس مفهوم الذات وصورة الآخر من إعداد الباحث وتم تطبيقه بعد الإثراف الكامل من

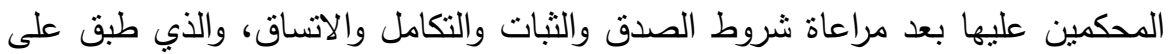
العينة الرئيسية المكونة من مجموع (Y) (Y) من الأحداث المودعين بالمؤسسات الإيداعية

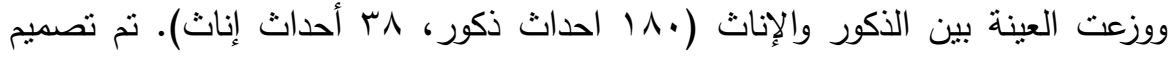
المقياس واختباره قبل توزيعه على مفردات عينة البحث من خلال عينة استطلاعية لمعرفة مدى وضوح الأسئلة، وبعد التأكد من ملائمة المقياس تم توزيعه على عينة البحث وتطبيقها.

مجالات الدراسة: إن إختبار مجالات الدراسة من الخطوات المنهجية التي لا بمكن إغفالها

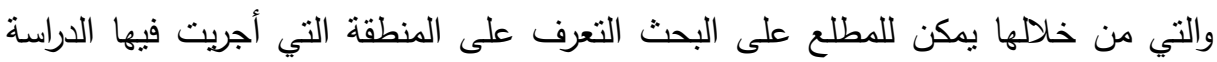

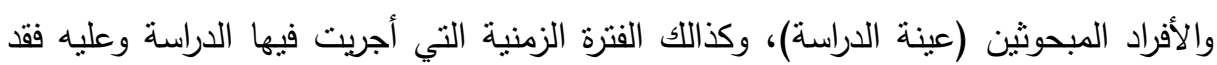

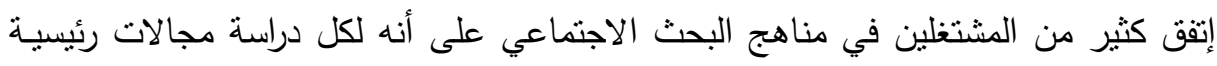
ثلاثة هي: المجال البشري، والمجال المكاني، والمجال الزمني. (إكرام سيد غلاب، مرجع 
المجال البشري: شملت عينة الدراسـة (1/ اYT) مفردة من الأحداث بمؤسسات الأحداث بالقاهرة

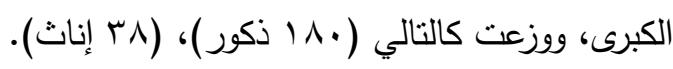

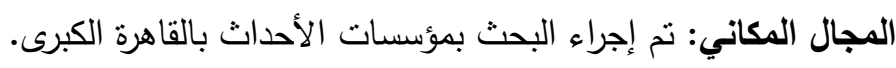

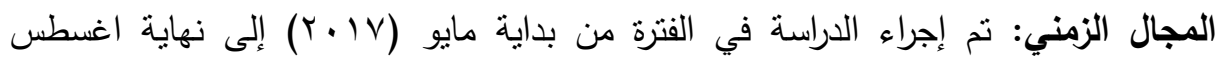
(Y. PV)

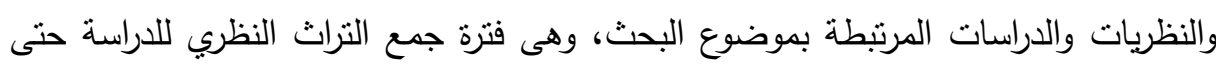
ثقوم على أسس موضوعية. مجتمع الاراسـة: لقد حاول الباحثون تجميع قدر من البيانات المنصلة بمفهوم الذات وصورة الآخر لدى عينة من الأحداث المودعين بمؤسسات الأحداث بالقاهرة الكبرى، وذالك فئك

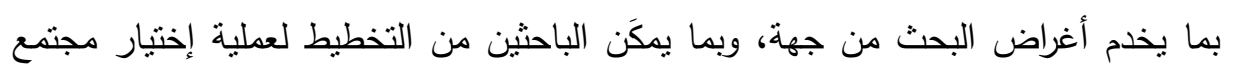

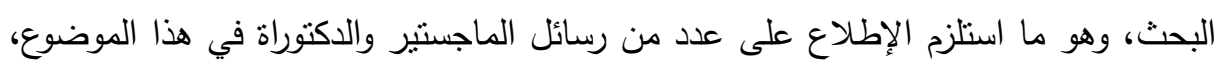

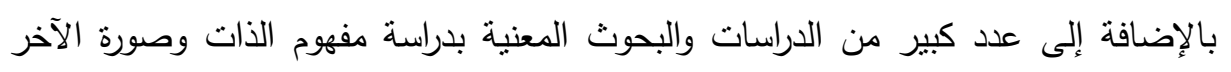
للأحداث المنحرفين، وقد حدد الباحثون بعد ذالك مؤسسات الأحداث بالقاهرة الكبرى لكي تجري بها الدراسـة الميدانية والبحث. الزيارات الإستطلاعية: لقد قام الباحثون بعدد من الزيارات الإستطلاعية لمجتمع البحث

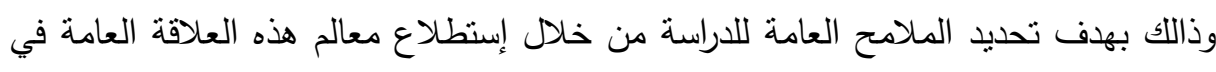

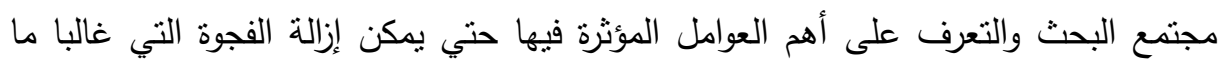

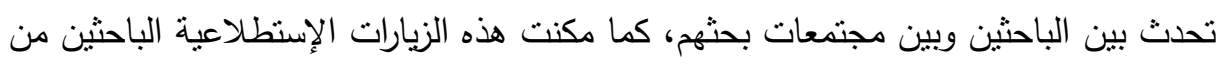

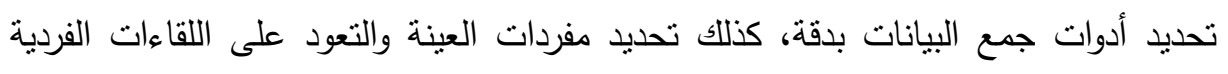

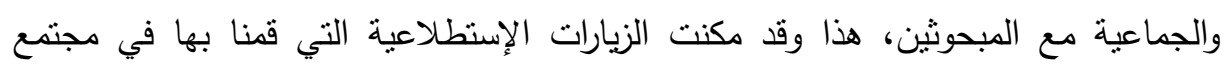
البحث من تغطية هذه الجوانب، بما مكننا من الإعداد الجيد والدقيق للبحث الميداني وتهيئة المناخ اللازم لإنجازه بدقة. حجم عينـة الدراسـة: كانت هناك شروط لاى الباحثين عند إختيار عينــة الدراسـة: ( ) أن ينم إختبار عينة الأحداث المنحرفين من مؤسسات الأحداث بالقاهرة الكبرى.

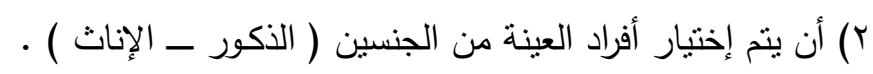




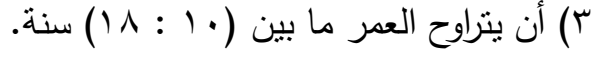

$$
\begin{aligned}
& \text { §) مراعاة التجانس بين أفراد العينة في شتي المتغيرات. }
\end{aligned}
$$

ولقد بلغ حجم العينة الكلية (Y) (Y) حدثا من الذكور والإناث، تتراوح أعمارهم ما بين

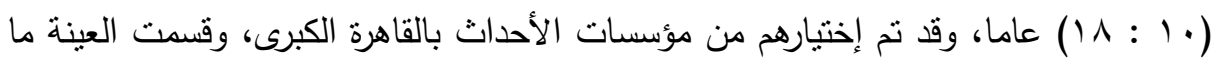

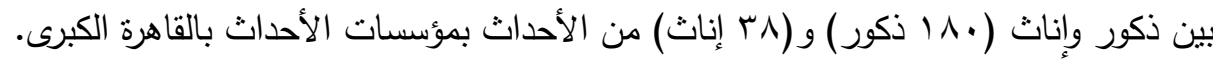

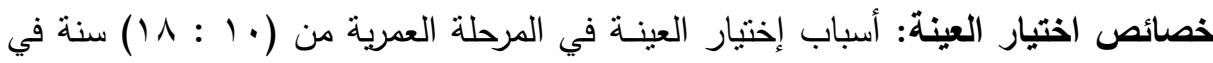

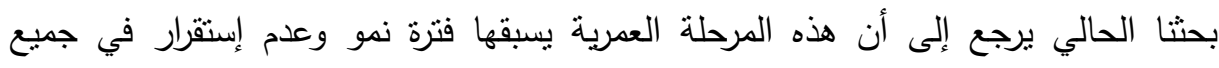

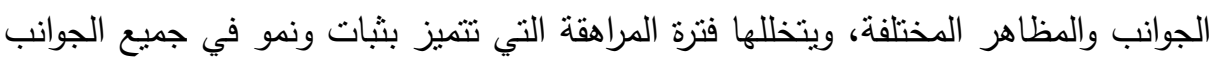
والمظاهر المختلفة لمفهوم الذات واستكماله في هذه الفترة ولا يتغير بعد ذالك بل يبقى نسبيا

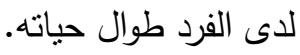

والباحثون فضلوا هذه المرحلة العمرية (• ( : 1) سنة حيث نتميز بالطفرات في

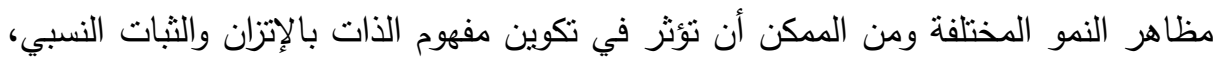
وتتصف هذه الفترة بالتمركز حول الذات وإدراكها للآخر وتأثرها به. وصف المقياس: يتكون المقياس من (•ـ () بندا يمثل كل منها مظهرا من مظاهر مفهوم الذات وصورة الآخر للأحداث المنحرفين، وتتدرج كل منهما تحت أربعة أبعاد أساسية لمفهوم الذات وصورة الآخر (البعد النفسي والإجتماعي لمفهوم الذات، والبعد النفسي والإجتماعي لصورة الآخر )، ويقوم المفحوص بإعطاء إجابة واحدة لكل بند من بنود المقياس (موافق ) أو والو

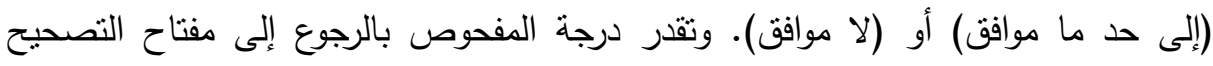
الخاص بالمقياس، بحيث تعطي درجة واحدة لكل إجابة تتفق مع المفتاح، وفي النهاية ينت

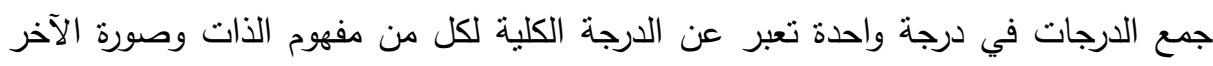

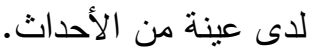


محتوى المقياس: يستخدم المقياس في التعرف على مفهوم الذات وصورة الآخر في إطار

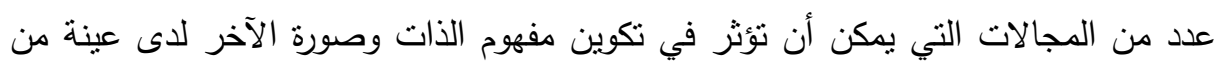

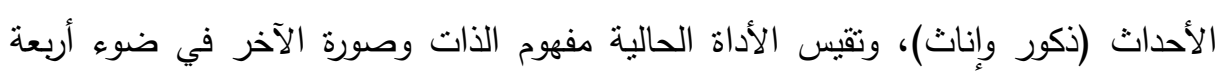
عوامل رئيسية:

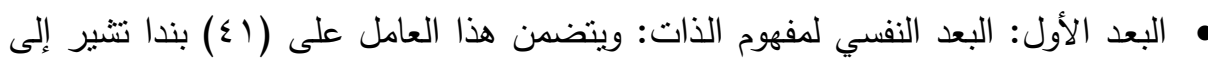
الحالة النفسية للحدث، ومفهومه عن ذاته، ومدى نقلب مزاجه، نظرته للمستقبل، تأنيب

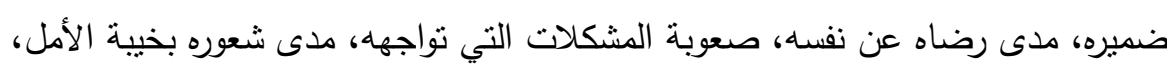

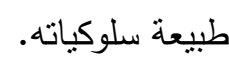
•البعد الثاني: البعد الاجتماعي لمفهوم الذات: ويتضمن هذا العامل على (9 (1) بندا تشير

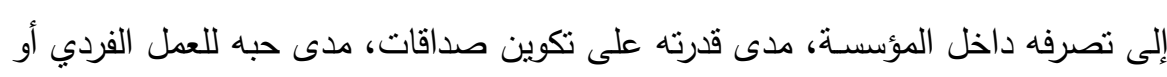
الجماعي. • البعد الثالث: البعد النفسي لصورة الآخر: ويتضمن هذا العامل على (•؛) بندا تثير

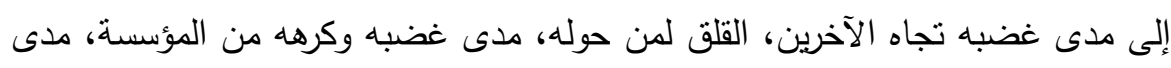
نظرته للمشرفين، مظاهر حرمانه من الرعاية، مدى شعوره بالذل والقهر داخل المؤسسة.

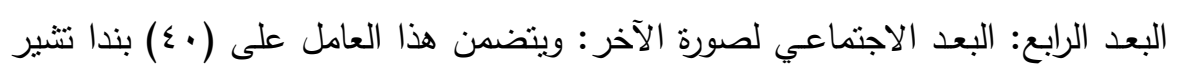

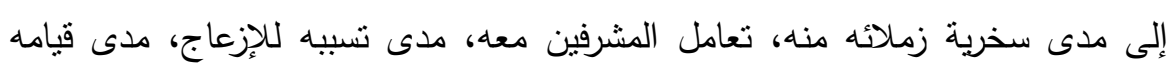

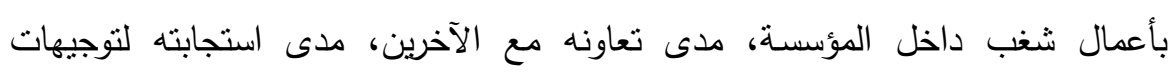
المشرفين، هل يشعر بحب الآخرين له ومدى إحساسه بتقبل الآخرين.

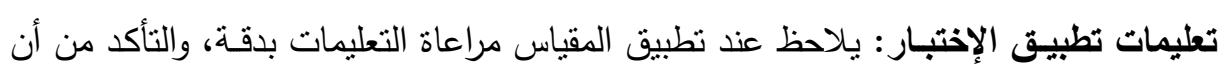

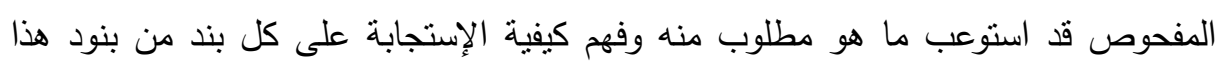
المقياس. لذا نوصي بأن يقوم الباحثون بتهيئة الجو المناسب للنطبيق من حيث المكان، ويقوم بقراءة التعليمات الخاصـة ونطق الإجابة بصوت واضح، ويبدأ الدفحوص الإجابة.

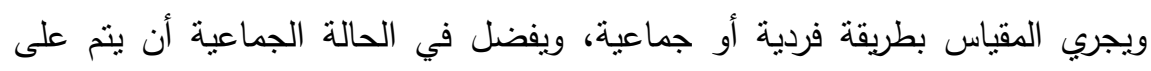
مجموعات صغيرة حتي يتأكد الباحث من تفهم الحالات لإجراء المقياس. 
حساب درجـة المفحوص: لكل بند من هذا المقياس ثلاث إستجابات (موافق، إلى حد ما

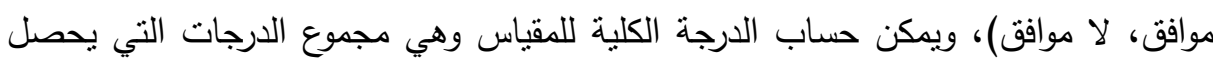

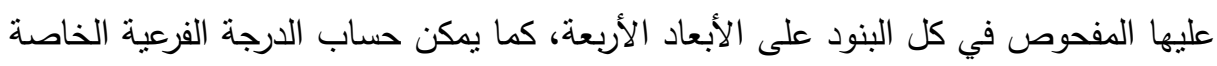

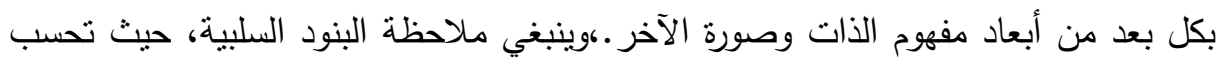
الدرجة بصورة عكسية (أنظر مفتاح التصحيح). التحليل السيكومتري للمقياس: صدق المقياس: بعد أن قام الباحثُن بالخطوات الأوليـة في بناء المقياس، التي أثنير إليها في

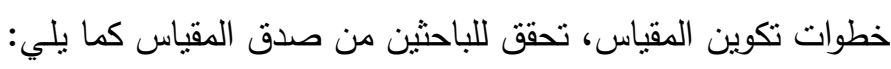

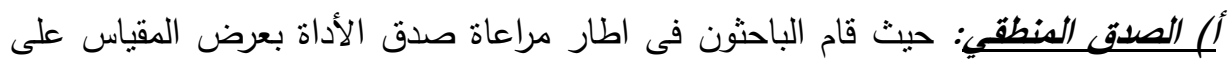

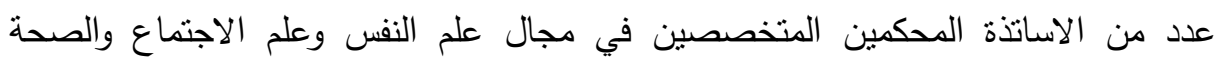
النفسية بهدف تقييمه وتوضيح رؤيتهم فى تحقيق الأداة لأهداف الدراسة، وقد قرر السادة

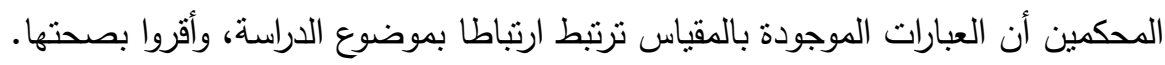

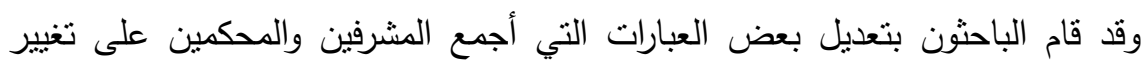
صياغتها حتي تصبح أكثر وضوحا لعينة النقنين. ب) الصدق العاملي: إستخدم الباحثون أسلوب التحليل العاملي لإستخراج معاملات الإرتباط

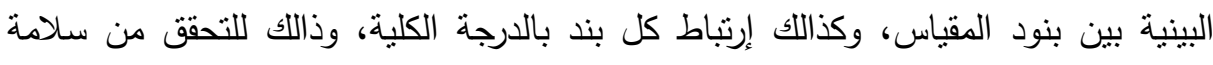
البناء الداخلي للمقياس، كما إستخدم الباحثون نفس الأسلوب بعد ندوير المحاور في إستخراج العوامل الأساسية التي ينكون منها المقياس.

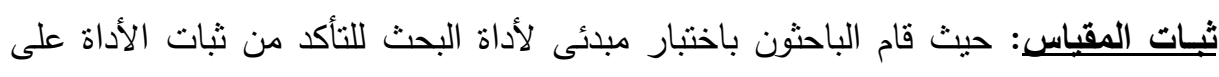

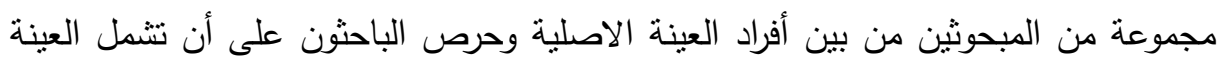
خصائص مجتمع الدراسة، وذللك لاختبار الثبات الاحصنئئى للأداة. 


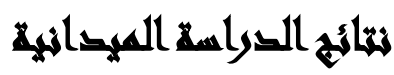

التحليل الإحصائي للمقياس: نم تقريغ البيانات عن طريق البرنامج الإحصائي المعروف Statistical Package For Social Sciencesبرنامج الحزم الإحصائية للعلوم الاجتماعية لون وتم التحليل الإحصائي باستخدام الحاسب الإلى من خلال برنامج الحزم الإحصائية SPSS

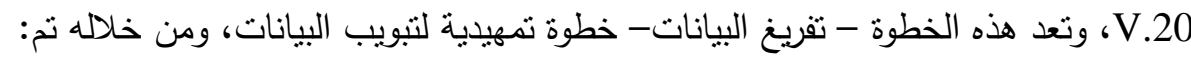

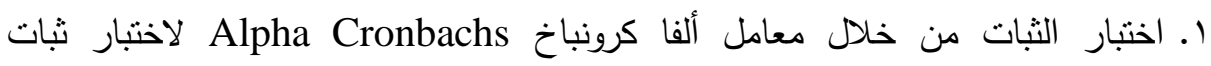
المقياس. r. اختبار صدق الاتساق الداخلي من خلال معامل إرتباط بيرسون بين الأبعاد وإجمإلى المقياس. r. الإحصاءات الوصفية للبيانات من خلال جدولة البيانات في صورة نكرارات ونسب مئوية لأسئلة استمارات المقياس.

ع. إيجاد العلاقات الإرتباطية بمعامل ارتباط بيرسون لمحاور الدراسة.

ه. المتوسط والانحراف المعياري باستخدام اختبار T test لمعرفة اتجاه أراء عينة الدراسة.

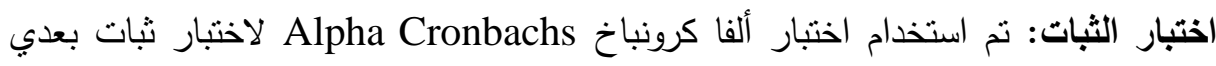

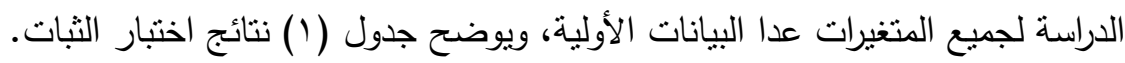

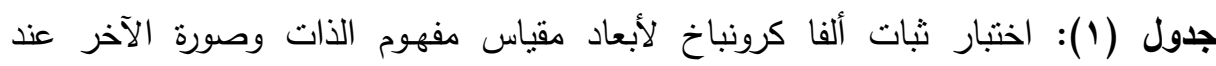

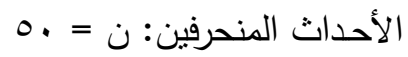

\begin{tabular}{|c|c|c|}
\hline عدد العبارات & معامل ألفا & المتغيرات \\
\hline §! & $\cdot, \lambda Y \varepsilon$ & البعد النفسى لمفهوح الذات \\
\hline 19 & $\cdot, \wedge 1 \wedge$ & البعد الاجتماعي لـفهوم الذات \\
\hline$\xi$. & 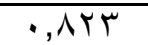 & البعد النفسي لَصـورة الآخر \\
\hline$\xi$. & $\cdot, \wedge 17$ & البعد الاجتماعي لصورة الآخر \\
\hline
\end{tabular}

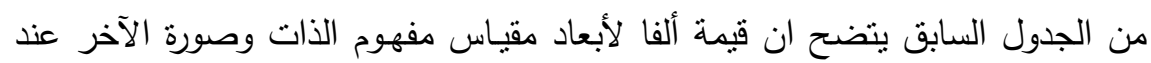
الأحداث المنحرفين (البعد النفسي لمفهوم الذات، البعد الاجتماعي لمفهوم الذات، البعد لإنداد

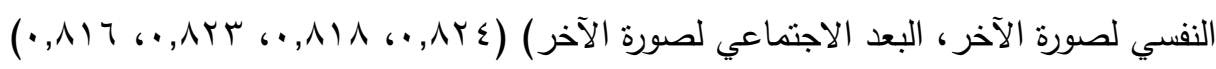

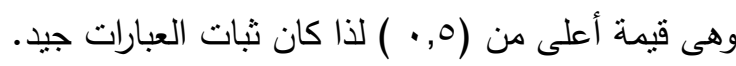


صدق الإتساق الااخلي: ولمزيد من التحليل، فقد قام الباحثون بحساب صدق الإتساق الداخلي

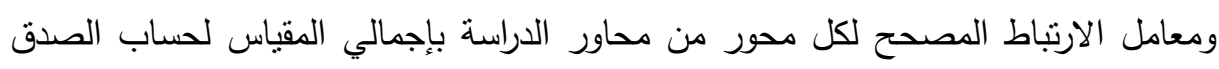
كالآتي: جدول (r): صدق الاتساق الداخلي لأبعاد مقياس مفهوم الذات وصورة الآخر عند الأحداث

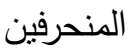

\begin{tabular}{|c|c|c|}
\hline المقياس ككل & \multicolumn{2}{|c|}{ المتغيرات } \\
\hline$(* *) \cdot, 997$ & معامل ارتباط بيرسون & \multirow{2}{*}{ البعد النفسي لمفهوم الذات } \\
\hline$\cdot, \cdots 1$ & الدلالة المعنوية & \\
\hline$(* *) \cdot 69 \wedge V$ & معامل ارتباط بيرسون & \multirow{2}{*}{ البعد الاجتماعي لمفهوم الذات } \\
\hline$\cdot, \cdots 1$ & الدلالة المعنوية & \\
\hline$(* *) \cdot, 997$ & معامل ارتباط بيرسون & \multirow{2}{*}{ البعد النفسي لصورة الآخر } \\
\hline$\cdot, \cdots 1$ & الدلالة المعنوية & \\
\hline$(* *) \cdot, 994$ & معامل ارتباط بيرسون & \multirow{2}{*}{ البعد الاجتماعي لصورة الآخر } \\
\hline$\cdot, \cdots 1$ & الدلالة المعنوية & \\
\hline
\end{tabular}

من الجدول السابق نجد أن الدلالة المعنوية لأبعاد مقياس مفهوم الذات وصورة الآخر

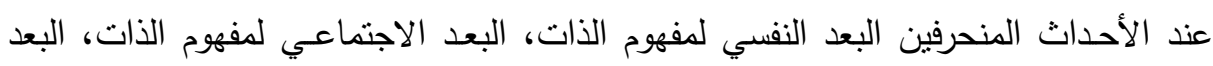

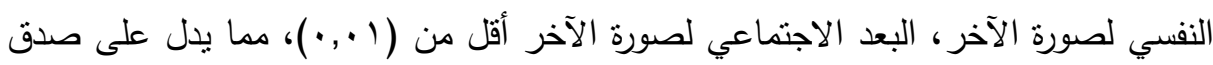
الاتساق الداخلي للمقياس. جدول (r): اختبار T test للفروق بين مفهوم الذات لاى عينة من الذكور والإناث داخل

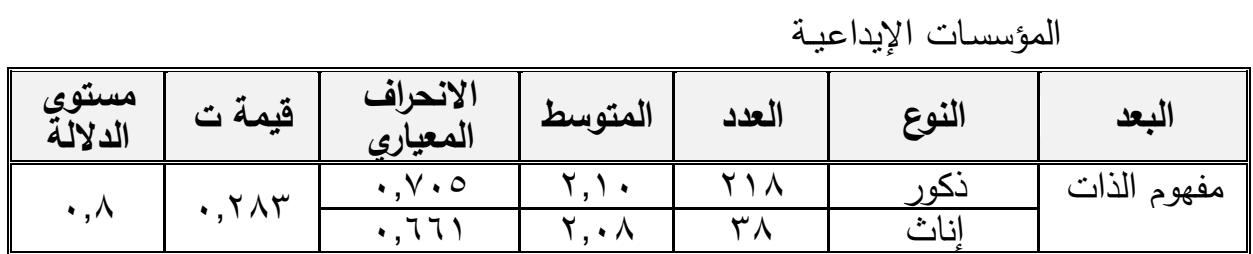

يوضح الجدول السابق انه لا نوجد فروق بين الذكور والإناث في مفهوم الذات داخل

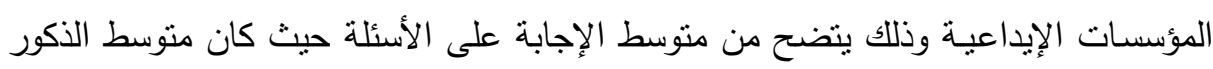

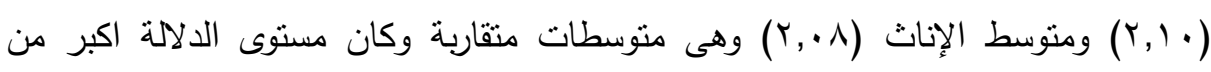


جدول (§): اختبار Test للفروق بين صورة الآخر لدى عينة من الذكور والإناث داخل

\begin{tabular}{|c|c|c|c|c|c|c|}
\hline & & & \multicolumn{4}{|c|}{ المؤسسات الإيداعية } \\
\hline مستوية & قيمة ت & الالاتحرافي & المتوسط & العدد & النوع & البعد \\
\hline \multirow{2}{*}{$\cdot, 0$} & \multirow{2}{*}{$\cdot, 79 r$} & $\cdot, 791$ & $T, 10$ & YIA & ذكور & \multirow{2}{*}{ صورة الآخر } \\
\hline & & $\cdot, 7 \vee 9$ & $T, \cdot T$ & rᄉ & إناث & \\
\hline
\end{tabular}

يوضح الجدول السابق انه لا توجد فروق بين الذكور والإناث في صورة الآخر داخل

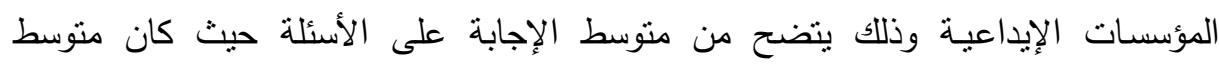

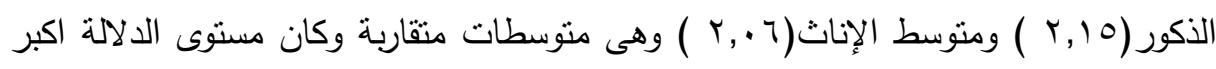
جدول (ه): العلاقة بين الذكور والإناث لـفهوم الذات وصورة الآخر داخل المؤسسات

\begin{tabular}{|c|c|c|}
\hline & & الإيداعية \\
\hline ذكور & إناث & \multirow{2}{*}{ مفهوم الذات } \\
\hline \multicolumn{2}{|c|}{ صورة الآزر } & \\
\hline$(* *) \cdot .9997$ & 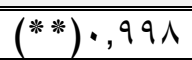 & معامل الارتباط \\
\hline$\cdot, \cdots 1$ & $\cdot, \cdots 1$ & مستوى الدلالة \\
\hline
\end{tabular}

يوضح الجدول السابق انه توجد علاقة ارتباطيه بين مفهوم الذات وصورة الآخر داخل

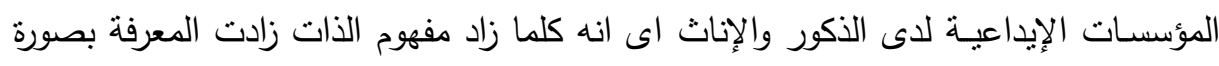
الآخر وذللك يتضح من خلال معامل الارتباط للاككور (997, •) ومعامل الارتباط للإناث

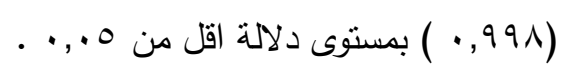
تفسير النتائج المتعلقة بمقياس البعد النفسي والإجتماعي لمفهوم الذات: للتحقق من التساؤل الأول القائل: "ما مقارنـة مفهوم الذات لدى عينة من الذكور والإناث

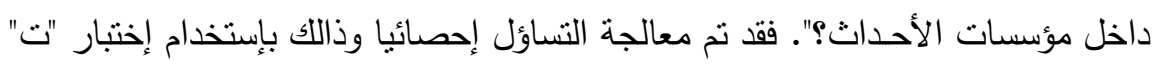
T - TEST لحساب دلالة الفروق حيث أنه:

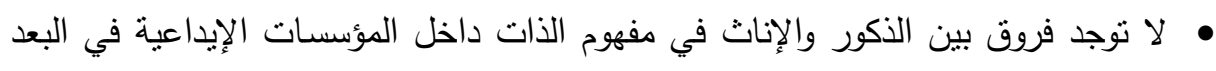
النفسي واتفق الذكور والإناث في نسب الموافقة على العبارات (أشنعر بأنني إنسان محمل بالأوجاع والآلام، أشعر بأنني عندما أكبر سأتغير للأحسن، أود أن أكون مختلفا عما أنا 
به، أشعر بأنني عندما أكبر سأتغير للأحسن، أثنعر أني مضطرب في جميع الأحوال، أحس أني سريع الغضب وعنيف). مأما الذكور فكانت أكثر العبارات المعبرة عن مفهوم الذات في البعد النفسي لديهم (أنشعر

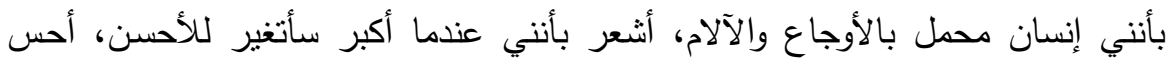

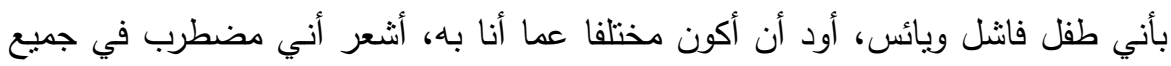
الأحوال، أشعر بالقلق في نومي، أحس أني سريع الغضب ونات وعنيف).

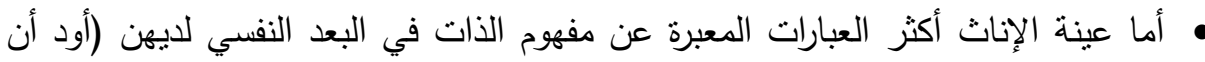

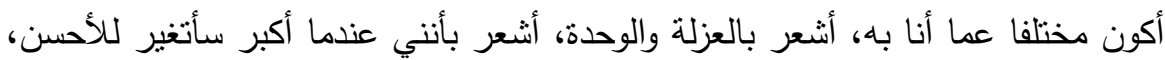

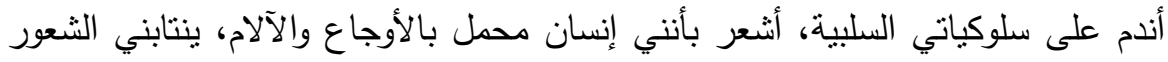

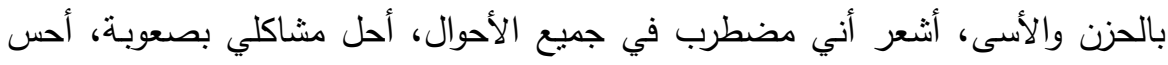
أني سريع الغضب وعنيف، أشعر بأنني إنسان بلا أمل ولا مستقبل نطاردني الأحلام

$$
\text { والكوابيس المزعجة). }
$$

• لا توجد فروق بين الذكور والاناث أيضا في البعد الاجتماعى لدفهوم الذات بالنسبة لعينة الذكور كانت أكثر العبارات التى تعبر عنهم هى (أحتفظ بصداقات متعددة، أتصرف التهات

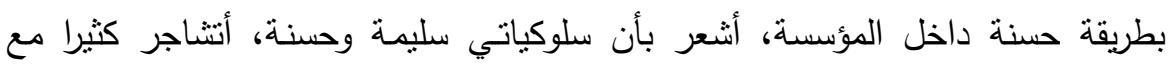
زملائي). • أما عينة الإناث كانت أكثر العبارات النى حصلت على نسب موافقة فى البعد الاجتماعى التئ

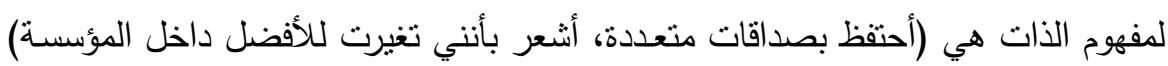

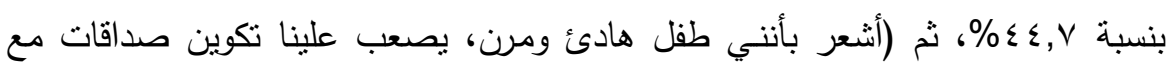
الآخرين، أسامح الآخرين بسهولة، أنتاجر كثيرا مع زملائي).

\section{تفسير النتائج المتعلقة بمقياس البعد النفسي والإجتماعي لصورة الآخر:}

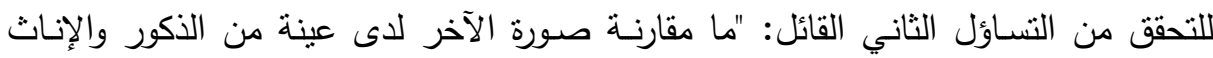

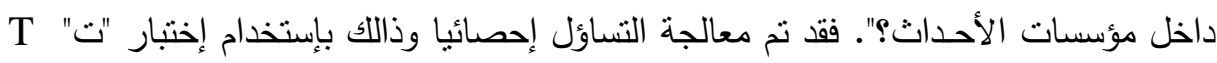
TEST

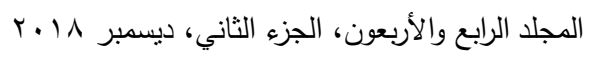


• لا توجد فروق بين الذكور والإناث ايضا في البعد النفسي لصورة الآخر وكانت أهم

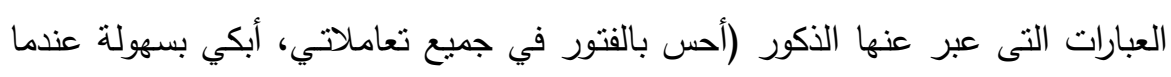

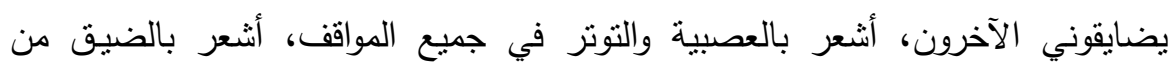

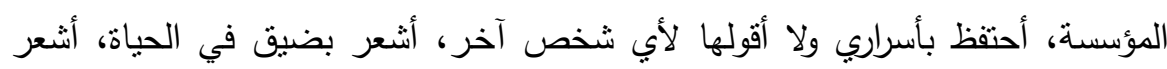
بالدونيـة عندما أتواجد مع الآخرين).

• وكانت أهم العبارات التى عبر عنها الإناث في البعد النفسي لصورة الآخر هي (أشعر التحر

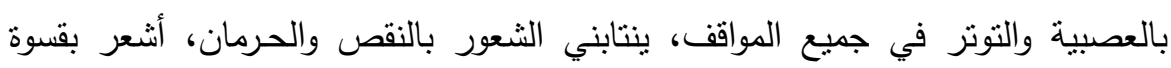

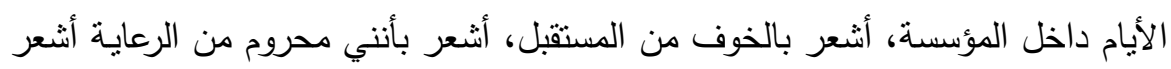
بالضيق اتجاه الآخرين، أثنعر بالقلق لمن حولي، أحس بالفتور في جميع تعاملاتي).

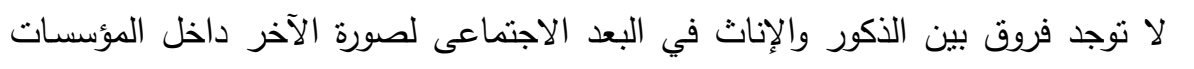
الإيداعية واتفق الذكور والإناث في نسب الموافقة على العبارات (أحب التواجد مع أسرتي) أكثر العبارات التى حصلت على نسب موافقة عند الذكور هى (يصعب علي تلكوين

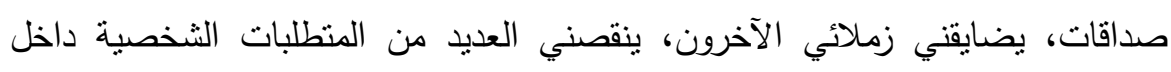

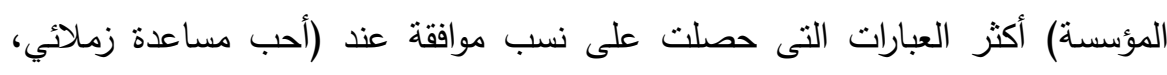

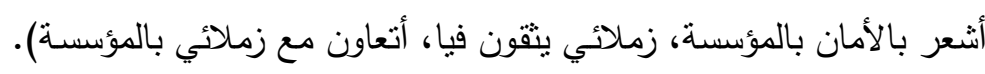

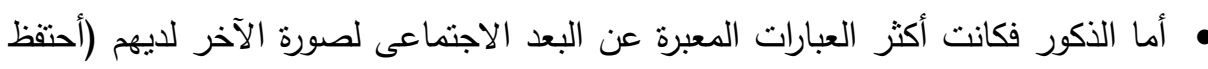

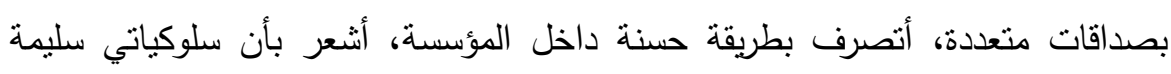

$$
\text { وحسنة، أنتاجر كثيرا مع زملائي). }
$$

• أما عينة الإناث فكانت أكثر العبارات المعبرة عن البعد الاجتماعى لصورة الآخر لديهن (أحتفظ بصداقات متعددة، أثنعر بأنني تغيرت للأفضل داخل المؤسسة، أشنعر بأنني طفل الإنل

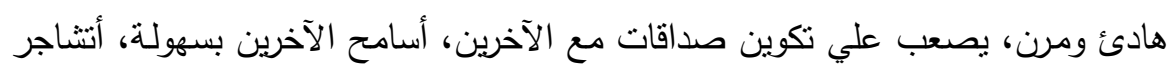

$$
\text { كثيرا مع زملائي). }
$$

للتحقق من التساؤل الثالث القائل: "ما طبيعة العلاقة بين الذكور والإناث لمفهوم الذات وصورة الآخر داخل مؤسسات الأحداث؟". فقد نم معالجة التساؤل إحصائيا وذالك بإستخدام إختبار "ت" T - test لحساب دلالة الفروق حيث الأن النه: 
توجد علاقة طردية بين مفهوم الذات وصورة الآخر داخل المؤسسات الإيداعية لاى الذكور والإناث أي أنه كلما زاد مفهوم الذات زادت المعرفة بصورة الآخر ، وكلما قل مفهوم الذات قلت المعرفة بصورة الآخر •

\section{المراليع}

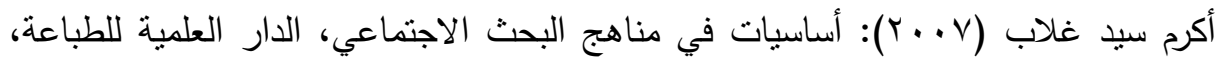
دمنهور، القاهرة

الجمعية العامة للافاع الاجتماعي : المؤتمر العاشر بو9 199، البحث الثاني

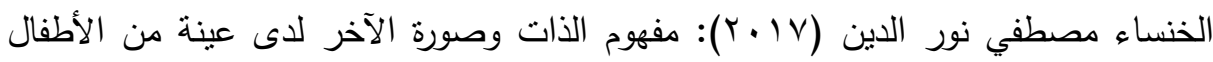
ساكني المقابر ، رسالة ماجستير، معهد البحوث والدراسات البيئية، جامعة عين من الاطن شمس.

حامد عبد السلام زهران (99V1): علم النفس الاجتماعي، الطبعة الرابعة، القاهرة: عالم الكتب.

حلمي المليجي (9VY ()): علم النفس المعاصر، دار النهضة العربية للطباعة والنشر، طب. رمضان محمد القذافي (997 (1): الثخصية: نظرياتها وإختباراتها، وأساليب قياسها، الطبعة الثانية، بنغازي، دار الكتب الوطنية.

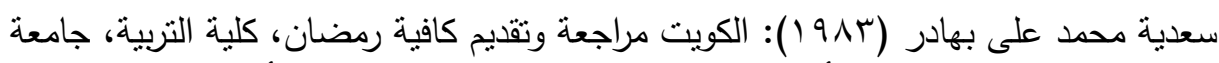

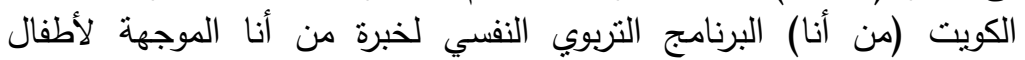
الرياض بين النظرية والتجربة، مركز بحوث التربية المناصبح، الكويت.

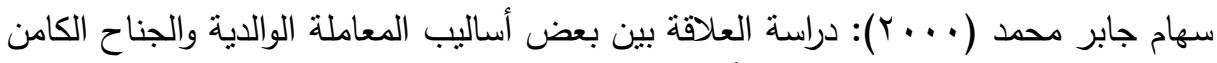

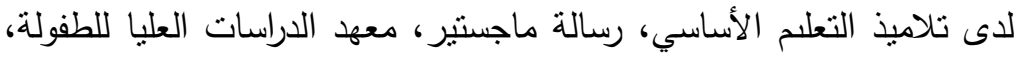

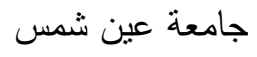
عبد الباسط محمد حسن (•99 (19): أصول البحث الاجتماعي، مكتبة وهبة، الطبعة الحادية عشرة، القاهرة.

فاطمة محمود محمد يوسف: إنحراف الأحداث في المناطق العشوائية، دراسة لأنماط التشئة

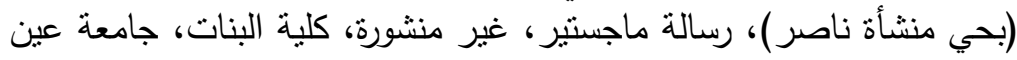

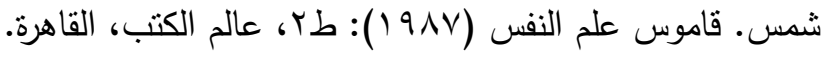

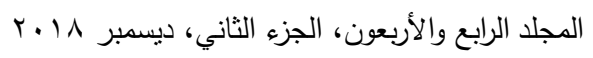


فاطمة مقدم (Y ( † Y): فعالية برنامج إرشادي جماعي في تحسين مفهوم الذات لدى الأحداث

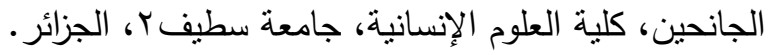

فاتن عبد الفتاح السيد (919 (1)): اتجاهات الوالدين نحو أطفالهم وأثر ذاللك على مفهومهر

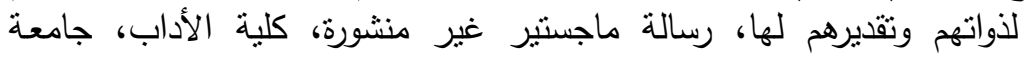

$$
\text { الزقازيق. }
$$

فتحي أبو العينين، تحرير الطاهر لبيب (999 (19): صورة الذات والآخر في الخطاب الروائي،

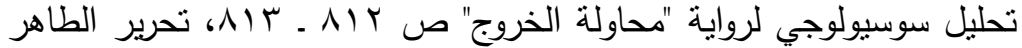

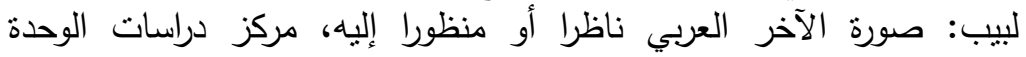

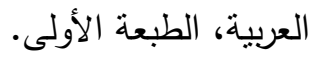

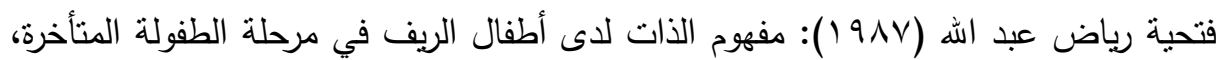
رسالة ماجستير ، كلية الأداب، جامعة الزقازيق.

فرج عبد القادر طه (ب991): موسوعة علم النفس والتحليل النفسي، الكويت، دار سعاد

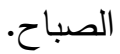

فؤاد البهي السيد (·191): علم النفس الاجتماعي، الطبعة الثالثة، دار الكتاب الحديث،

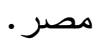

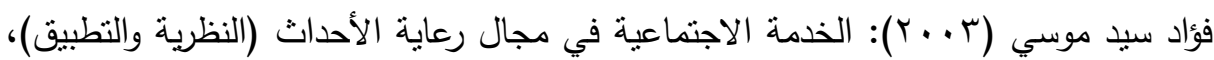
مكتبة النهضة العربية، القاهرة.

مجمع اللغة العربية: المعجم الوجيز (•99.19): مجمع اللغة العربية، القاهرة: الهيئة العامة لثشؤن المطابع الأميريـة.

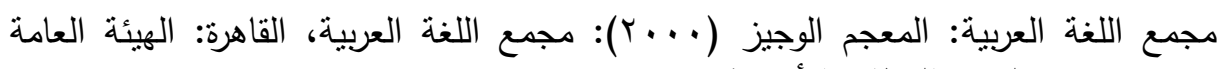
لشؤن المطابع الأميريـة.

محمد سيد خليل وآخرون (0 × ب): مدخل إلى علم النفس التجريبي، القاهرة، دار الحريري

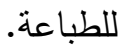

محمد شفيق (0. . ب): أساليب البحث العلمي بين النظرية والنطبيق، دار المعارف، الإسكندرية.

محمد عماد الدين إسماعيل (9V7 (1)): كيف تعمل الجماعات، الهيئة المصرية العامة للكتاب،

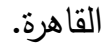

معوض عبد التواب (990): مرجع في شرح قانون الأحداث، دار المطبوعات الجامعية، 


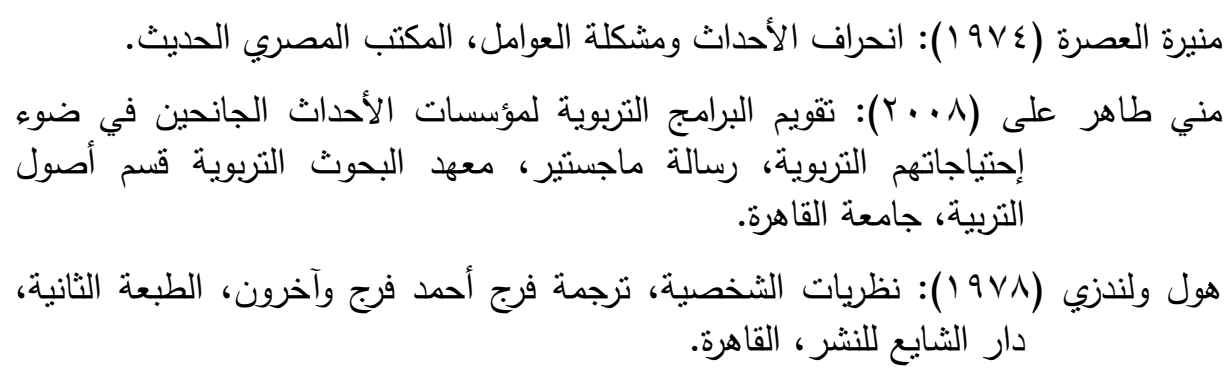

Hieder, F. (1971): Perceiving The Person In Hollander, E. \& Hunt, R., Currentperspective In Social Psychology, University Press.

Hoshi; Akemi; Evelyn (2001): Juvenile Delinquency in Salzburg, Austria: A Self report Study, MA University of Massachusetts, Lowell.

Mishel, W. (1981): Introduction to Psychology, New York: library of Congress.

Monel, Jack Santiago (2005): Early Precursors of Social-Problem in juvenile delinquents, and their relationship to adult criminal behavior, P. H. D., Walden University, Minnesota, United States.

Neil, O.; Green, B. \& Theyns, D. (1991): A Self-concept scale for the hearing-impaired. The volta Review, 1991, vol.1, pp. 19-29.

Owens-Sabir-Sahasin-Cecelia (2005): The Continuum of Control and Self-esteem a Study of delinquency, P.H.D., Mississippi state University.

Second, P. \& Beckman, Cal. (1964): Social psychology, megrew Hill Book Company.

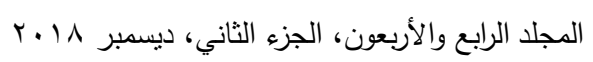


أحمد أحمد محمد محمد بدر وآخرون

\title{
SELF - CONCEPT AND THE OTHER'S IMAGE AMONG SAMPLE OF JUVENILES IN INSTITUTIONS IN GREATER CAIRO
}

\author{
Ahmed, A. M. Badr ${ }^{(1)}$; Amal, Abdel Fatah ${ }^{(2)}$ \\ and Reem, A.Ibrahim ${ }^{(3)}$
}

1) Institute of Environmental Studies \& Research, Ain Shams University 2) Faculty of Education, Ain Shams University 3) Faculty of Physical Education, Helwan University

\begin{abstract}
The person constantly tries to identify the depths of the same to determine the direction and personality traits, and that is an urgent attempt in adolescence of the human life, and this needs continue for the rest of his life, depending on the changes and the environment, so that the concept of self is the center of the personality, composition and construction of humanity. The first psychologists pointed out that society is only a mirror in which the individual sees himself, and the individual begins to form a self-defined concept from the very first moment of his life where he begins to gather information about himself and the others surrounding him in the environment, and the environment in which he lives and belongs, to be the result of his interaction, friction and dealings with the social environment in which he lives a lot of emotions, emotions and sensations that accumulate day after day and quickly learns how to relieve his pain and sorrows and how to overcome the difficulties and obstacles faced in life as he realizes at the same time what he feels With psychological relief, and the full motivation of his motives, provoking his tendencies and brought to his attention, and this study to recognize the comparison of the concept of self and the image of the other in a sample of male and female juveniles within the juvenile institutions in Greater Cairo, the study sample included (218) individual for both males and females, and divided The sample is as follows (180) Single male juveniles, 38 single

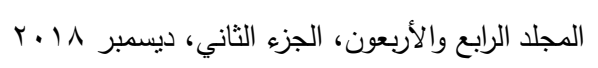




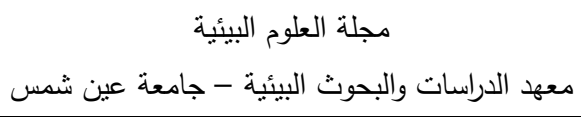

female juveniles. This study belonged to the descriptive study and the researchers used the comparative analytical descriptive approach, using regular random sample, the researchers used the preliminary data form and then use the measure of self-concept of the work of the researchers to measure the psychological and social dimension of the concept of self and the image of the other sample of research, as the researchers relied on some statistical methods in the study including the test of Ttest, and costs, percentages, averages and standard deviation. It is clear from the statistical analysis that the alpha value of the exclusion of the self-concept and the image of the other in juvenile delinquents (psychological dimension of self-conception, social dimension of the concept of self, the psychological dimension of the image of the other, the sociological aspect of the image of the other) $(0.824,0.818,0.823$, 0.816) Value is higher than (0.5) so it was a good firming. For further analysis, the researchers calculated the sincerity of internal consistency and the corrected correlation coefficient for each of the study's axes with the total scale to calculate the honesty the moral significance of the dimensions of the self-concept and the image of the other in juvenile delinquents in the psychological and social dimension is less than (0.01), demonstrating the sincerity of the internal consistency of the scale.

The present study has reached the following conclusions: There are no statistically significant differences between males and females in the psychological and social dimension of the concept of self within the juvenile institutions in Greater Cairo.

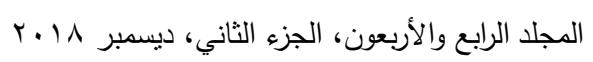

